\title{
Are Banking Crises Really an Equal Opportunity Menace?
}

\author{
Vincent Bouvatier ${ }^{1+}$, Yamina Tadjeddine ${ }^{2}$ \\ ${ }^{1}$ Université Paris Est Créteil, France / CEPII, France \\ ${ }^{2}$ Université de Lorraine, France
}

\begin{abstract}
This paper investigates exposure to banking crises. Based on a long-term perspective and descriptive statistics, Reinhart and Rogoff $(2008,2009)$ and Qian et al. (2011) concluded that banking crises are equal opportunity menaces in the sense that both advanced and developing economies face the same exposure. This paper confirms this result, relying on the hazard function of a duration model. Moreover, we extend the concept that banking crises are an equal opportunity menace in two directions. First, we show that graduation from inflation, currency, or debt crises does not reduce the exposure to banking crises. Second, we indicate that top banking centers do not have a higher exposure to banking crises.
\end{abstract}

Keywords: Banking crisis, Discrete-time duration model

JEL Classifications: G01, G21, C41

Received 10 July 2019, Revised 31 August 2019, Accepted 7 October 2019

\section{Introduction}

Reinhart and Rogoff's (2008) seminal paper renewed the empirical field of financial crises through a large historical database that covered 70 countries over more than two centuries. Their book (Reinhart \& Rogoff 2009) became a cornerstone of financial history literature, providing numerous statistical analyses and original interpretations. However, their results have also been critically analyzed. The first set of criticisms concerns the statistical treatment that proved their stylized facts. As mentioned by Parent (2012), Reinhart and Rogoff (2008, 2009) based their explanations on apparent correlations and provided only a descriptive analysis. Several critical comments particularly focused on the relationship between the $90 \%$ public debt threshold and economic growth (Herndon et al. 2014, Égert 2015). The second set of criticisms is concerned with their way of addressing economic history without considering the cultural, political, and institutional differences across countries and over time. The main differentiation criterion used by Reinhart and Rogoff is the income level of countries. However, this criterion might be

\footnotetext{
+Corresponding Author: Vincent Bouvatier

Professor, Université Paris Est Créteil, ERUDITE, 61, avenue du Général de Gaulle, 94010 Créteil Cedex, Email: vincent.bouvatier@u-pec.fr

Co-Author: Yamina Tadjeddine

Professor, Université de Lorraine, BETA, 13 place Carnot, 54035 NANCY Cedex, France, Email: yamina.fourneyron@un iv-lorraine.fr
} 
considered insufficient to capture a potential heterogeneity between countries in the frequency of financial crises. This second set has primarily been introduced by economic historians (Calomiris \& Haber 2014, Parent 2012). According to Calomiris and Haber (2014), "the fragility of banks and the scarcity of bank credit reflect the structure of a country's fundamental political institutions" (p.12).

First, this paper proposes to provide an econometric basis for one of Reinhart and Rogoff's stylized facts: the equal opportunity menace of banking crises. More precisely, Reinhart and Rogoff (2008, 2009) and Qian et al. (2011) investigate the risks of recidivism for different types of financial crises and introduce the concept of graduation to describe the absence of recurrence of banking and financial crises. According to their results, advanced economies seem to have graduated from default and inflation crises. However, no subset of countries has graduated from banking crises. Therefore, banking crises are considered an equal opportunity menace, occurring similarly in high-, middle-, and low-income countries. In particular, the database provided by Reinhart (2010) can be used to assess the average exposure to a banking crisis from a long-term perspective. This database shows that the average probability of a banking crisis was $3 \%$ over the period 1800 2010.1) This frequency captures the unconditional probability that a banking crisis occurs and corresponds, as regards periods, to a crisis every 33 years on average. To investigate this stylized fact in depth, we followed Bouvatier (2017) and relied on a duration model to assess exposure to banking crises.

The duration model provides a complementary insight into the risk of banking crises. Indeed, duration models serve to identify the hazard function that characterizes banking crises, which gives the variation over time in the conditional probability that a banking crisis occurs given an elapsed duration since the last banking crisis. The hazard function does not suggest that banking crises occur in a deterministic manner but rather identifies whether banking crises occur more frequently over a specific duration. Therefore, the shape of the hazard function captures the risk of a banking crisis in a dynamic setting. A high recurrence translates into higher probabilities of surviving a crisis when long durations without a crisis are reached as this situation is rarely observed. According to the equal opportunity menace of banking crises (Reinhart \& Rogoff 2008, 2009, Qian et al. 2011), it might be expected that the hazard function should not depend on the income level of countries.

Second, this paper considers supplementary differentiation criteria to investigate graduation from banking crises. Reinhart and Rogoff (2008, 2009) and Qian et al. (2011) use only one criterion to discriminate between countries: income level and, more precisely, the income group classification by the World Bank. Their results show that this criterion is not meaningful; average

1) Only the initial years of banking crises are considered to compute this probability. Therefore, the $3 \%$ probability level is associated with the number of independent events. If all the years in crisis (not just the initial ones) are considered, the average banking crisis probability is approximately $8 \%$ (i.e., the average duration of banking crises is 2.5 years). 
exposure to banking crises is not related to economic development. Evidently, some of the most developed countries are also those most exposed to banking crises. For instance, the United Kingdom and the United States have recorded the largest numbers of banking crises (14 and 13, respectively, using the database of Reinhart (2010) over the period 1800 2010). However, the third-ranked country is Brazil. Furthermore, several high-income countries, such as Australia, New Zealand, and Canada, recorded fewer banking crises. In this paper, we use two alternative criteria to consider some institutional differences between countries.

We started with an original differentiation based on graduation from other financial crises. We especially investigated whether the occurrence of banking crises depends on the occurrence of other types of financial crises. For instance, after the 1997 Asian financial crisis, Kaminsky and Reinhart (1999) introduced the term "twin crises" to describe the simultaneous occurrence of banking and currency crises. Most empirical papers (Kaminsky \& Reinhart 1999, Glick \& Hutchison 1999, Eichengreen \& Arteta 2000) found that the occurrence of a banking crisis can precede and lead to a currency crisis. However, the opposite does not hold; in other words, the occurrence of a currency crisis is not a significant leading indicator of a new banking crisis. Here we propose to revisit this phenomenon and assess the influence of non-banking financial crises generally (i.e., currency, debt, and inflation crises) on the occurrence of banking crises using a duration model.

Turning to the second alternative criterion, we introduced an institutional differentiation between countries related to the status of international banking centers. Fernand Braudel, a French historian, published a three-volume book about the European origins of capitalism (Braudel 1982). He adopted a longue durée approach $(1400 \sim 1800)$ to highlight the existence of long-term cycles in the capitalist economy. Each long-term cycle is associated with the preeminence of particular cities (Venice and Genoa 1250 1510, Antwerp 1500 1569, Amsterdam, 1570 1733, London 1733 1896). The world economy was organized with a core city, a developed middle zone around it, and a periphery. The core city dominated the commercial, industrial, and financial transactions inside the world economy for a certain period. Braudel (1982) observed that the dominant cities had certain common features, particularly control over the credit supply. Kindleberger (1974) deepened this idea by focusing exclusively on financial centers, and Cassis (2010) described this long history as the "capitals of capital." Each long-term cycle is characterized by a hierarchical network of financial cities: global, regional, and national centers. This idea of hierarchical financial centers in the global network is also found among geographers of finance (Reed 1981, Choi et al. 1986, Sassen 1991, Sassen 1999, Corbridge et al. 1994, Cottrell 2007). Consequently, we investigated whether the prevalence of banking crises depends on the position of the country in the international money circuit. In other words, countries with top-ranked banking centers might be more exposed to banking crises. Such an empirical investigation requires a database identifying banking centers over a long-term perspective. 
The contributions of this paper are twofold. First, we contribute to the literature on the quantitative history of financial crises, bringing new insights into the prevalence of banking crises from a long-term perspective. We relied on discrete-time duration models to obtain a quantitative assessment of exposure to banking crises, and we documented and highlighted some original stylized facts about the prevalence of banking crises. Our major findings are as follows: (1) the shape of the hazard function obtained for banking crises is not extremely different between advanced and other economies; (2) the occurrence of currency and inflation crises increases the risk of banking crises; (3) countries that have graduated from external debt, currency, or inflation crises (i.e., recording long durations without such crises) do not benefit from a lower exposure to a banking crisis; and (4) the major banking centers are not more exposed to the recurrence of banking crises. These results were mainly obtained by introducing interaction variables in a discrete-time duration model to capture whether the hazard function deviates from the baseline function for a subgroup of countries. Several robustness checks were implemented, particularly concerning the sample size and the definition of interaction variables. The results support the equal opportunity menace of banking crises highlighted by Reinhart and Rogoff (2008, 2009) and Qian et al. (2011), the empirical evidence shows that the hazard function does not meaningfully depend on the income level of countries.

Further, considering alternative specifications of the discrete-time duration model, we successively assessed whether countries prone to non-banking financial crises and with major banking centers face a higher risk of recidivism of banking crises. In particular, the results support the chain of causation that runs from currency to banking crises suggested by Stoker (1995): the empirical evidence shows that countries in a currency or a post-currency crisis period face a higher risk of falling into a banking crisis. The hazard functions are not meaningfully different between countries that have gone decades without a currency crisis and those that have gone more generally without a non-banking financial crisis. We also found that the hazard function does not meaningfully deviate from the baseline regarding major banking centers. Therefore, the results allow the extension of the concept of banking crises as an equal opportunity menace that was introduced by Reinhart and Rogoff (2008, 2009) and Qian et al. (2011).

Second, the empirical analysis implemented in this paper required the identification of banking centers over a long-term perspective. Therefore, based on Reed (1981), Choi et al. (1986), Choi et al. (2014), and qualitative works by historians (such as Kindleberger 1974 and Cassis 2010), we compiled a new database that ranks banking centers over more than two centuries.

The remainder of the paper is organized as follows: Section II describes the criteria used to differentiate between countries. Section III presents the empirical models. Section IV presents the results and discusses the different shapes of hazard functions. Section V concludes the paper. 


\section{Differentiation Criteria in the Prevalence of Banking Crises}

In this section, we present the databases used to identify banking crises and the three criteria that we used to investigate differences between countries in the prevalence of banking crises: income level, the prevalence of other financial crises, and the status of major banking center.

\section{A. Prevalence of banking crises}

First, we have to specify the set of banking crises considered in this paper. The main objective was to get a large sample that covered many countries over a long time span. We merged the banking crises database of Reinhart (2010), which identifies the episodes of banking crises in 70 countries across the period 1800 2010, with the banking crises database of Laeven and Valencia (2013), which covers 162 countries over the period 1970 2011, to specify our baseline sample.2) Reinhart (2010) and Laeven and Valencia (2013) used events methodology to identify banking crises. However, Chaudron and de Haan (2014) indicated that most banking crises databases that use events methodology are inherently subjective. Thus, the Reinhart (2010) and Laeven and Valencia (2013) databases have not identified the same banking crises for countries and periods. For a robustness check, a smaller sample including only the banking crises identified by Reinhart (2010) was used to estimate the models.

The banking crises reported in the Reinhart (2010) and Laeven and Valencia (2013) databases may have occurred over the course of several years. The treatment of these multi-year events is important to analyze the frequency of banking crises and to compute the time elapsed since the last crisis. The standard recommendation for these multi-year events (Beck et al. 1998) was to drop all but the initial year of the banking crisis and to set the duration of time without a banking crisis to 1 when countries have a first year without a banking crisis. Then, each banking crisis event is associated with a single year and yearly observations can be treated as independent of one another. ${ }^{3}$ )

The baseline sample used to estimate the baseline specification was composed of 10,047 observations from 148 countries and covered 336 banking crises. Therefore, banking crisis episodes represent approximately $3.34 \%$ of the sample, which corresponds to the unconditional probability of a banking crisis occurring. As regards periods, banking crises occur on average every 30 years.

2) The Reinhart (2010) database was used as the primary source owing to its long time span. The Laeven and Valencia (2013) database was then used to include countries and periods that are missing in the Reinhart (2010) database.

3) Therefore, the duration and the depth of banking crises were disregarded. We note, however, that the average duration of a banking crisis is 2.18 years. Moreover, $60 \%$ of the banking crises occurred over a single year and $88 \%$ did not happen over more than 3 years. Lastly, mean-comparison tests show that we have no systematic difference in duration of banking crises between advanced and non-advanced countries and between banking centers and other countries. 


\section{B. Income level}

The relationship between financial development and economic growth is not apparent. According to Levine's (2005) seminal papers, a positive relationship exists between economic performance and financial development, which can be explained by better public information, better private monitoring, a higher quality of institutions, a higher quality of regulations, and so on. Banking crises might be expected to be less frequent in advanced countries as they have more developed financial systems. Therefore, the income-level criterion can be logically considered to determine differences between countries in the frequency of banking crises. However, another segment of the literature questions this positive relationship and states the importance of the credit channel (Minsky 1986). Recently, some empirical findings have suggested that excessive growth in the financial sector can harm real growth (Cecchetti \& Kharroubi 2015). Therefore, advanced countries might be more prone to financial instabilities and credit crunches and may potentially face more banking crises.

We relied on Gross Domestic Product (GDP) per capita to investigate the ambiguous relationship between the income levels of countries and the prevalence of banking crises. We used GDP per capita normalized by year, given by $G D P_{i, t}^{\text {PerCap }}=\left(z_{i, t}-\bar{z}_{,, t}\right) / \sigma_{(z, t)}$ where $z_{i, t}$ is the GDP per capita for country $i$ at year $t, \bar{z}_{, t,}$ and $\sigma_{z, t}$ are the mean and the standard deviation, respectively, of GDP per capita at year $t$ computed over the whole set of countries available in the databases. ${ }^{4)}$ In sum, the normalization ensures we get a stationary and time-varying indicator that annually ranks countries by level of economic development. We also relied on the income group classification provided by the World Bank for a robustness check (Reinhart and Rogoff 2008, 2009, Qian et al. 2011) to divide countries into three groups: high-, middle-, and low-income levels. The current method of classification used by the World Bank dates to 1987 and is based on gross national income per capita. Hence, in a long-term perspective (i.e., 1800 2010), the composition of income groups is considered time-invariant when the income group classification provided by the World Bank is used. Thus, alternatively using GDP per capita and income groups, we can examine whether the hazard function characterizing banking crises depends on economic development.

\section{Exposure to non-banking financial crises}

Exposure to banking crises might be related to exposure to other categories of financial crises. Over the last two centuries, numerous inflation, currency, and debt crises have been recorded (Reinhart 2010). These categories of crises may interact and appear to be closely associated with banking crises in some scenarios.

4) Data sources are reported in Appendix 1. 
After the publication of the famous A Monetary History of the United States, 1867 1960 by Friedman and Schwartz (1963), many research studies have dealt with the consequences of high inflation on the real economy. Especially, under high inflation, the circulation of cash money is higher, which dramatically decreases deposits in banks. For instance, the hyperinflation during the Weimar Republic in Germany in 1922 1923 induced major bank difficulties (Balderston 1991). When considering banking sector problems during the period 1980 1994, Demirgüç-Kunt and Detragiache (1998) also noticed that banking crises tend to erupt when inflation is high. Therefore, it can be expected that the chain of causation runs from inflation to banking crises.

Second, banking and currency crises may be closely related, and this relationship was closely examined following the 1997 Asian crisis (Kaminsky \& Reinhart 1999). According to Bordo et al. (2001), the twin crises were regular occurrences during the interwar period, non-existent in the heyday of the Bretton Woods agreement, and have become more frequent since 1973. As mentioned previously, empirical findings suggest that the main causal chain runs from banking to currency crises. However, the reverse chain of causation (from currency to banking crises) can emerge in some scenarios. Stoker (1995) and Mishkin (1996) claim that the economic environment generated by a currency crisis (e.g., loss of international reserves, high interest rates, and exchange rate devaluation) can destabilize domestic banks, especially if numerous debts are denominated in a foreign currency.

Third, banking and debt crises also interact. The 2008 European sovereign debt crisis has renewed the interest in such interactions (Bank for International Settlements [BIS] 2011). In particular, the causal chain that runs from debt to banking crises emphasizes that debt crises can lead to a depreciation of banks' asset holdings and to an increase in banks' funding costs.

The number of causal chains that might potentially lead to a banking crisis can vary substantially across countries, particularly if some countries have graduated from a subset of non-banking financial crises. In other words, graduation from inflation, currency, or debt crises might reduce the occurrence of banking crises. Therefore, we differentiated between countries according to their degrees of graduation from inflation, currency, or debt crises, which we assessed by the time elapsed since the last inflation, currency, or debt crisis, respectively. We also examined whether the hazard function characterizing banking crises changes with the time elapsed since the last inflation, currency, or debt crisis.

\section{Banking centers}

Economic historians such as Braudel (1982), Kindleberger (1974), and Triffin (1964) highlighted the different roles played by countries inside the world financial system. The core of the international money network concentrates the major financial and banking institutions in one location, holds a large portion of the gold or currency reserves, has more developed money 
and capital markets, and is open to foreign investors. This segmentation between central and peripheral countries is helpful for examining the occurrence of crises. For instance, Bordo et al. (2001) and Triffin (1964) noticed that under the gold standard, financial instabilities were greater in peripheral countries than in central countries. Conversely, central countries were more crisis prone during the interwar period.

This idea of hierarchical financial centers in the global network is found among geographers of finance (Reed 1981, Choi et al. 1986, Sassen 1991, Sassen 1999, Corbridge et al. 1994, Cottrell 2007). We relied on this literature to build an original database that identifies the major banking centers over the period 1800 2010.

Geographers of finance outline the different ways to characterize a financial center. Especially, they make a distinction between financial and banking centers. According to Reed (1981), a financial center is a city with a high concentration of financial institutions that clear international financial transactions. A banking center is a place where the largest international commercial and private banks are located. In this paper, we solely focus on the long-term evolution of the world's major banking centers to examine whether this status matters for the frequency of banking crises. To the extent of our knowledge, Reed's (1981) was the first statistical contribution to show the hierarchical structure of international banking centers and its evolution over the period 1900 1980. For the period 1900 1980, Reed (1981) selected (on a five-year basis) the largest international banks by the size (i.e., assets and deposits) and the number of foreign offices. He then examined the location of these international banks and retained 76 cities. The cities were ranked according to the number of active offices of the international banks recorded. Hence, Reed (1981) obtained a hierarchical ranking of banking centers over the period 1900 1980.

For the contemporaneous period (1980 2010), we referred to the ranking of the world's banking centers proposed by Choi et al. (1986) and Choi et al. (2014). Similar to Reed (1981), they started by delimiting a sample of cities characterized by significant banking activities. Then, they considered the 300 largest banks in the world and noted where those banks located their head office and their representation in other centers. They applied network analysis to determine the hierarchical position of each city; and the rank of the city was dependent on its degree of centrality inside the global banking network. Rankings for the years 1970 and 1980 are both available in Reed (1981) and Choi et al. (2014). They proposed similar rankings of major banking centers despite the differences in their methodologies.5) The classifications made by Reed (1981) and Choi et al. (2014) were merged and a database of major banking centers covering the period 1900 2010 was obtained.

5) Choi et al. (1986) and Choi et al. (2014) focused on a limited number of banking centers compared to Reed (1981). Only14 cities were considered. As a result, over the full sample, only top-ranked banking centers can be properly tracked while regional/mid-scale banking centers might only be identified over the 1900 1980 period from Reed (1981). In other words, the specific situation of regional/mid-scale banking centers cannot be controlled for in our empirical analysis. 
For earlier periods (1800 1900), we relied on the qualitative work of historians Kindleberger (1974) and Cassis (2010). We constructed our own ranking of banking centers. For instance, the two historians recount the competition between Amsterdam, London, and Paris during the 19th century and they provided some turning points in financial history. Cassis (2010) relates the decline of Amsterdam at the beginning of the 19th century in particular, and then indicated that after 1840, Paris became more attractive for banking activities than Amsterdam. We interpreted this narrative history by changing the ranking in the classification of banking centers.

We eventually obtained a database of major banking centers over the period 1800 2010 that we used to differentiate between countries. Some countries have different banking centers (e.g., the United States with New York, Los Angeles, San Francisco, and Boston or Italy with Milan, Genoa, and Rome). Therefore, we considered that the ranking of a given country corresponded to the best ranking of its cities. Moreover, according to the various sources used to rank banking centers over the period 1800 2010, and bearing in mind the inherent subjectivity of the final ranking, we used the database to identify the top eight countries with major banking centers (and the top five for a robustness check) so as to not give too much weight to the places in the ranking. The top eight countries were allowed to generally cover the global financial centers identified by Reed (1981). In other words, we examined whether the hazard function characterizing banking crises differs for countries with a top-ranked banking center.

\section{The Empirical Models}

We followed Bouvatier (2017) to specify the baseline model. The baseline specification was used to identify the hazard function characterizing banking crises. Next, we expanded the baseline specification to examine whether the shape of the hazard function characterizing banking crises depends on the three differentiation criteria discussed in the previous section.

\section{A. The baseline model}

We used a pooled discrete-time duration model to estimate the hazard function for banking crises. This model is a logit specification including a spline function to capture the time dependence, and the baseline model is as follows:

$$
P\left(Y_{i, t}=1\right)=\frac{1}{1+\exp \left[-X_{i, t} \beta-\sum_{j=0}^{n} b_{j} \text { Basis }_{j, i, t}^{\text {banking }}\right]},
$$

where the subscripts refer to country $i$ in period $t$. The variable $Y_{i, t}$ is a binary variable that 
is equal to 1 if a banking crisis occurs and equal to 0 otherwise; $X_{i, t}$ is a set of covariates; and $\beta$ is a vector of parameter estimates. The covariates $X_{i, t}$ are considered control variables. In particular, economic development is controlled to assess whether advanced economies have a lower exposure to banking crises. However, the main objective of the estimate is to capture the time dependence (i.e., the hazard function).

The variables $\operatorname{Basis}_{j}^{\text {banking }}(j=0, \cdots n)$ are those used to capture the time dependence and $b_{j}(j=0, \cdots, n)$ are parameter estimates. The variables Basis $_{j}^{\text {banking }}$ are the basis variables obtained from a restricted cubic spline function. A spline function is defined as a smooth polynomial function that is piecewise-defined and thus provides a flexible tool to capture the time dependence. Especially, the spline function depends on the variable $d_{i, t}$ marking the duration of the sequence of zeros since the last crisis in country $i$ (with $d_{i, t}=1,2, \cdots, \mathrm{D}$ ). The places where the polynomial pieces connect are referred to as knots, and they serve to introduce changes in the relationship between the endogenous variable and the duration $d_{i, t}$. Computational details concerning the variables Basis $_{j}^{\text {banking }}$ are reported in Appendix 2, and a general presentation of discrete-time duration models can be found in Beck et al. (1998).

The parameters $\beta$ and $b_{j}$ are estimated by maximum likelihood, and the standard errors, which are obtained from the clustered version (i.e., on a national level) of the Huber-White estimator of the variance, are robust to heteroscedasticity.

\section{B. The control variables}

The set of covariates $\left(X_{i, t}\right)$ used in the baseline specification serves to control for transformations in the financial system and economic transformations across the long time horizon.

First, we controlled for the international environment and the national history of banking crises. We use the share of countries experiencing a banking crisis during the previous period ( $\operatorname{Share}_{t-1}^{\text {crisis }}$ ), which captures the international bunching of crises, and the judgmental capital mobility index (KMobility $y_{t-1}$ ) defined by Obstfeld and Taylor (2004) to control for the international environment. Furthermore, some countries have a long history of banking crises. As mentioned by Calomiris and Haber (2014), the distribution of banking crises is not random as it depends on long-term political and institutional structures. We introduced the number of banking crises experienced by the country since 1800 or since its independence $\left(\right.$ Count $\left._{i, t-1}\right)$, which controls for the national history concerning crises. ${ }^{6)}$ The variables Share $_{t-1}^{\text {crisis }}$, KMobility $_{t-1}$, and Count $_{i, t-1}$ are expected to positively affect the probability of a banking crisis.

Second, we included several dummy variables to account for the major changes in the

6) Furthermore, the variable Count $_{i, t-1}$ accounts for repeated events because second and subsequent crises are not independent of the number of previous crises (Beck et al. 1998). 
international monetary system. Therefore, the average probability of a banking crisis can vary across sub-periods. We used four dummy variables: $\operatorname{Period}_{t}^{1800 \sim 1820}$, Period $d_{t}^{1821 \sim 1913}$, Period ${ }_{t}^{1914 \sim 1945}$, and $\operatorname{Period}_{t}^{1946 \sim 1972}$, which are equal to 1 during the respective periods 1800 1820, 1821 1913, 1914 1945, and 1946 1972, and equal to 0 otherwise. The recent period (1973 2011) was used as the reference period. These boundaries were based on the main phases in international monetary history. The first sub-period (1800 1820) corresponds to Napoleon's empire, which induced some economic and monetary instability. In 1819, the Act for the Resumption of Cash Payments was voted in the United Kingdom and proclaimed gold convertibility. This act was in force in 1821, marking the beginning of the Gold Standard era, which culminated between 1870 and 1900 (Eichengreen \& Flandreau 1997) and ended in 1914 with World War I. We then distinguished the wars and interwar years (1914 1945) from the Bretton Woods period (1946 1972). The banking crises' frequency was quite different between these two sub-periods, with numerous banking crises during the interwar period and few during the Bretton Woods period. The coefficient associated with the variable Period ${ }_{t}^{1946 \sim 1972}$ is expected to be negative because few banking crises occurred during this financial repression period relative to the recent period. However, no expectations are expressed concerning the effects of the variables Period $_{t}^{1800 \sim 1820}$, Period ${ }_{t}^{1821 \sim 1913}$, and Period ${ }_{t}^{1914 \sim 1945}$.

Third, since the crisis incidence rate might depend on economic development, we relied on the GDPs per capita. We used the GDP per capita normalized by year $\left(G D P_{i, t-1}^{\operatorname{Per} C a p}\right)$ in the baseline specification.7) A negative and significant coefficient associated with the variable $G D P_{i, t-1}^{\text {PerCap }}$ would suggest that advanced economies graduate from banking crises while a non-significant coefficient would indicate that banking crises are an equal opportunity menace instead.8)

Finally, we controlled for the macroeconomic environment. We especially control for inflation, including the variable Inflation $_{i, t-1}$ corresponding to the $\log$ of 1 plus the inflation rate multiplied by 100 . This variable notably captures hyperinflationary episodes.9)

7) As indicated in subsection II-B, $G D P_{i, t}^{\text {Per } C a p}=\left(z_{i, t}-\bar{z}_{., t}\right) / \sigma_{z, t}$ where $z_{i, t}$ is the GDP per capita for country $i$ at year $t, \bar{z}_{,, t}$ and $\sigma_{z, t}$ are the mean and the standard deviation, respectively, of GDP per capita at year $t$ computed over the whole set of countries available in the databases. In sum, the variable $G D P_{i, t}^{P_{e} C a p}$ annually ranks countries by level of economic development.

8) Reinhart and Rogoff $(2008,2009)$ and Qian et al. (2011) relied on the income categories defined by the World Bank to account for income levels. Dummy variables based on the income categories are used in an alternative specification to check the robustness of the results.

9) In a preliminary analysis, we have also considered the GDP gross rate and the standard deviation of the GDP gross rate computed on a moving-window of five years to control for the macroeconomic environment. However, these variables were never significant. Furthermore, in a preliminary analysis, we also controlled for the legal origin (French, British, or other). The variables accounting for the legal origin were not significant. We did not keep these variables to get a more parsimonious specification. 


\section{The augmented specifications}

The baseline specification was first expanded to investigate whether the time dependence (i.e., the hazard function) is different for advanced economies. Therefore, we used the following empirical specification:

$$
P\left(Y_{i, t}=1\right)=\frac{1}{1+\exp \left[-W_{i, t} \beta-\sum_{j=0}^{n} b_{j} \text { Basis }_{j, i, t}^{\text {banking }}-\sum_{j=0}^{n} b_{j}^{\text {high }} \text { Basis }_{j, i, t}^{\text {banking }} \times D_{i, t}^{\text {high }}\right],}
$$

where $W_{i, t} \equiv\left[X_{i, t} D_{i, t}^{h i g h}\right]$ is the set of control variables and $D_{i, t}^{h i g h}$ is a dummy variable equal to 1 if country $i$ is classified as a developed country at period $t$ and equal to 0 otherwise. Therefore, the interaction variables Basis $_{j, i, t}^{\text {banking }} \times D_{i, t}^{\text {high }}$ capture whether the hazard function is different for advanced economies. The 75 th percentile of the GDP per capita variable $\left(G D P_{i, t-1}^{\text {Per Cap }}\right)$ is used to define a developed country. ${ }^{10)}$

Second, we extended the baseline model to assess whether the time dependence is different for countries prone to non-banking financial crises. We allowed the time elapsed since the last currency, inflation, or external debt crises to affect the probability of having a banking crisis. Therefore, we used the following empirical specification:

$$
P\left(Y_{i, t}=1\right)=\frac{1}{1+\exp \left[-X_{i, t} \beta-\sum_{j=0}^{n} b_{j} \text { Basis }_{j, i, t}^{\text {banking }}-\sum_{j=0}^{n} b_{j}^{K} \text { Basis }_{j, i, t}^{K}\right]},
$$

with $K=$ currency, inflation, or debt. The variables Basis $_{j, i, t}^{\text {banking }}$ are the basis variables obtained from a restricted cubic spline function applied to the duration between banking crises, whereas Basis $_{j, i, t}^{K}$ are the basis variables obtained from a restricted cubic spline function applied to the duration between crises of type $K$ (i.e., currency, inflation, or debt crises). Therefore, the variables Basis $_{j, i, t}^{K}$ capture whether exposure to a banking crisis also changes with the time elapsed since the last crisis of type $K$.

Third, we extended the baseline specification to test whether the banking center status affects the incidence rate and the hazard function of banking crises. We use the following empirical specification:

10) For a robustness check, we also relied on the category of high-income countries defined by the World Bank to get an alternative definition of the variable $D_{i, t}^{\text {high }}$. However, the group of developed countries is time-invariant when this alternative definition is used. Furthermore, the two definitions classify $31 \%$ and $40 \%$, respectively, of the baseline sample in the group of developed countries. 


$$
P\left(Y_{i, t}=1\right)=\frac{1}{1+\exp \left[-Z_{i, t} \beta-\sum_{j=0}^{n} b_{j} \text { Basis }_{j, i, t}^{\text {banking }}-\sum_{j=0}^{n} b_{j}^{K} \text { Basis }_{j, i, t}^{K} \times \operatorname{Center}_{i, t}\right]},
$$

where $Z_{i, t} \equiv\left[X_{i, t}\right.$ Center $\left._{i, t}\right]$ is the set of control variables including the banking center status. In particular, the variable Center $_{i, t}$ is a dummy variable equal to 1 when country $i$ is identified as a top-ranked banking center in period $t$ in our banking center database presented in Section II and equal to 0 otherwise. The interaction terms Basis $_{j, i, t}^{K} \times$ Center $_{i, t}$ serve to identify whether the hazard rate is different between banking centers and other countries. Moreover, the variable Center $_{i, t}$ included in the set of control variables serves to identify whether the average incidence rate of banking crises is different between banking centers and other countries.

\section{Results}

\section{A. Baseline specification}

The estimate of the baseline specification, Equation (1), with the baseline sample is reported in column (1) of Table 1.11) The control variables highlight several interesting features of banking crises. For instance, the degree of capital mobility (KMobility $y_{t-1}$ ) affects the probability of a banking crisis positively and significantly at the $5 \%$ level. The international bunching of crises captured by the variable Share $_{t-1}^{\text {crisis }}$ is also supported at the $1 \%$ level, wherein the financial repression period $\left(\right.$ Period $_{t}^{1946 \sim 1972}$ ) is characterized by a lower probability of a crisis relative to the current period, whereas the period 1914 1945 exhibits a higher probability of a banking crisis than the current period.

The coefficient associated with the GDP per capita variable $\left(G D P_{i, t-1}^{\text {PerCap }}\right)$ is positive and significant at the $10 \%$ level in column (1) of Table 1 . This weakly significant coefficient suggests that advanced economies are more prone to banking crises. However, robustness checks show that this relationship between the GDP per capita variable and the probability of a banking crisis is not robust. In column (2) of Table 1, the baseline specification is estimated with the small sample composed only of the episodes of banking crises from the Reinhart database (2010). The results show that the GDP per capita variable is not significant anymore at the $10 \%$ level. The baseline sample includes many low- and middle-income countries from the early 1970s (not covered by the small sample) that recorded few banking crises. This change in the sample can explain why the result holds only in the baseline sample.

11) Descriptive statistics and data sources concerning the main variables used in the estimates are reported in Appendix 1 , and the variance inflation factors (VIF) and the correlation matrix were computed to ensure that there is no multicollinearity problem. 


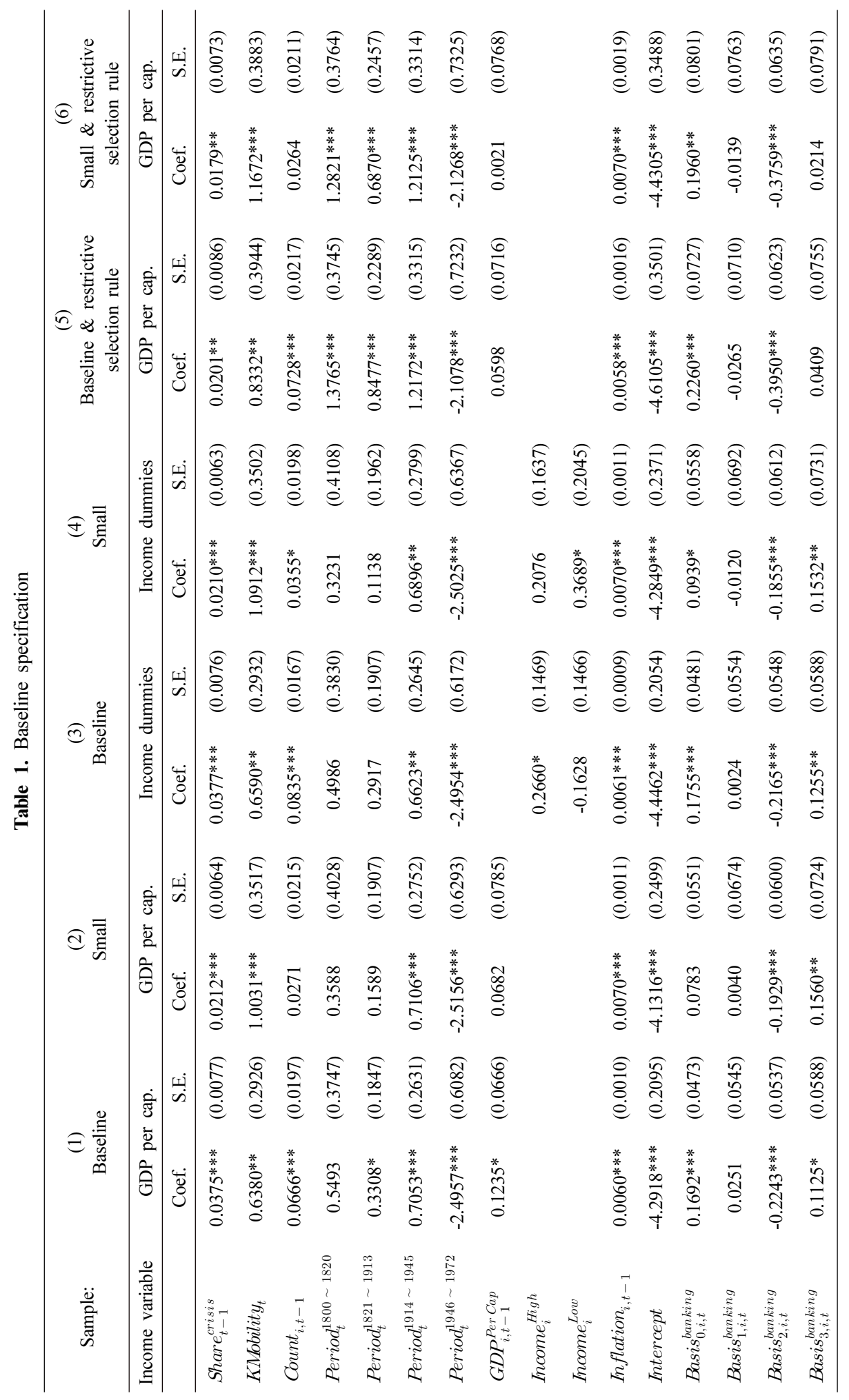




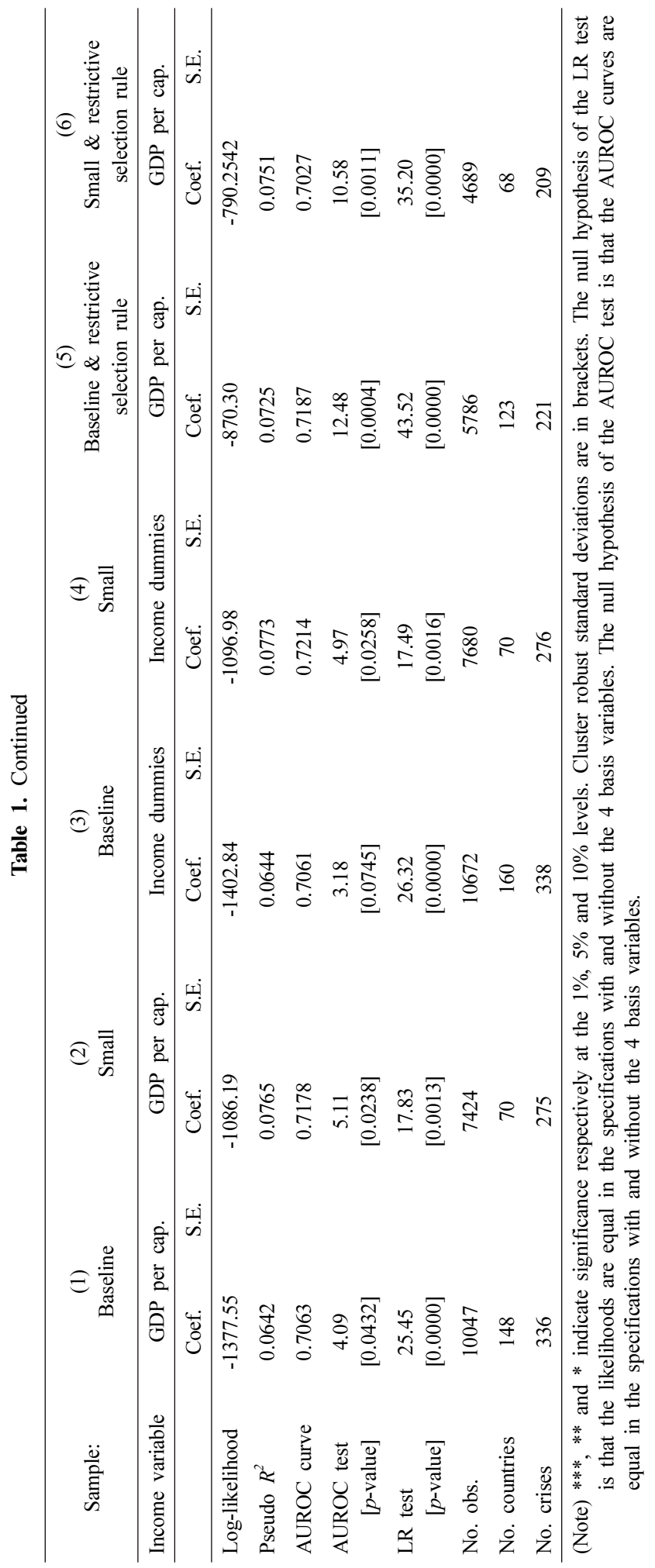


In columns (3) and (4) of Table 1, we used the income categories defined by the World Bank for robustness checks rather than the GDP per capita variable with the baseline sample and the small sample, respectively.12) We used two dummy variables, namely Income $_{i}^{\text {High }}$ and Income $e_{i}^{\text {Low }}$, which are equal to 1 if country $i$ is classified as high-income or low-income, respectively, and equal to 0 otherwise. Next, the intercept is associated with the situation of middle-income countries. Therefore, the coefficients associated with the variables Income $_{i, t}^{\text {High }}$ and Income $e_{i, t}^{\text {Low }}$ indicate whether the average probability of a crisis is different across income groups. The results in column (3) show that the probability of a banking crisis is higher at the $10 \%$ level in high-income countries than in low- and middle-income countries. However, as in the previous situation, this result is not robust in column (4) when the small sample is considered. Therefore, the effect of income level is sensitive to the sample of countries used.

The baseline and the small samples used to estimate the baseline specification reported in Table 1 can be considered as left-censored, because we have no information concerning crises dating prior to 1800 and some countries entered the dataset only after they became independent. Following Beck et al. (1998), the variable $d_{i, t}$ (marking the duration of the sequence of zeros since the last crisis) is set to 1 , when country $i$ entered the dataset, that is, in 1800 or when it became independent. However, the estimates might be affected by this selection rule. In particular, intervals before the first events (i.e., the first banking crisis in each country in this paper) might affect the estimate because these intervals are not precisely assessed or because the factors driving the first events might differ from those affecting the recurrences. Therefore, a more restrictive selection that kept only independent countries that had already faced a banking crisis in the samples was used as a robustness check.13)

The estimates are reported in columns (5) and (6) of Table 1 and correspond to the estimates reported in columns (1) and (2) of Table 1 when we added the constraint that the variable Count $_{i, t-1}$ is larger than 0 . The results suggest that the average exposure to a banking crisis does not depend on the level of economic development (i.e., the variable $G D P_{i, t-1}^{P e r C a p}$ is not significant at the $10 \%$ level in columns (5) and (6) of Table 1). The longest times spans before the first banking crisis are mainly recorded by developing countries, and thus, the result does not hold when the more restrictive selection rule is considered.

The main concern in the baseline specification is related to the variables Basis $s_{0, i, t}^{\text {banking }}$ to

12) The samples used in columns (3) and (4) are slightly larger than the ones used in columns (1) and (2), respectively, because the GDP per capita variable was no longer required.

13) We also used an alternative selection rule for a robustness check. We dropped observations before the first banking crisis (recorded in the databases) only for countries independent before 1800 because left censoring might be more noticeable for these countries. This alternative selection rule has by definition a more limited impact on the sample size than the restrictive selection rule considered in Table 1. The results obtained with this alternative selection rule lead to similar conclusions to the ones obtained without a selection rule. Therefore, these results are not reported to save space but are available upon request. 
Basis $_{3, i, t}^{\text {banking }}$, which correspond to the four basis variables obtained from the restricted cubic spline. We note in column (1) of Table 1 that three of these variables are significant at the $10 \%$ or $1 \%$ levels. Moreover, the likelihood-ratio (LR) test reported in column (1) of Table 1 indicates that the set of four variables used to control for time dependence is globally significant at the $1 \%$ level.

The ranking power of the model is evaluated by means of the area under the receiver operating characteristic (AUROC) curve as in Schularick and Taylor (2012) and Drehmann and Juselius (2014). ${ }^{14)}$ In column (1) of Table 1 , the AUROC curve is 0.7063 , which is close to the values obtained by Schularick and Taylor (2012) and can be considered as fair ranking power. Furthermore, the AUROC test (DeLong et al. 1988) in column (1) of Table 1 tests the equality of the AUROC curves when the variables Basis $s_{0, i, t}^{\text {banking }}$ to Basis $s_{3, i, t}^{\text {banking }}$ are excluded from or included in the model. The AUROC test indicates that equality is not supported at the $5 \%$ level. Hence, the ranking power of the model is significantly higher when we include the variables Basis banking .

Altogether, the estimates reported in Table 1, the LR test, and the AUROC test conclude that the hazard rate is not flat. Thus, we conclude that the probability of a banking crisis is characterized by a time-dependence effect. However, the estimated coefficients associated with the variables Basis $_{j, i, t}^{\text {banking }}$ cannot be directly interpreted. They are used to make hazard plots that represent the probability of a banking crisis as a function of the time elapsed since the last banking crisis. The hazard plot generated from the estimate reported in column (1) of Table 1 is displayed on Figure 1-a. We normalize the average probability of a crisis at 0.50 (i.e., we set all the covariates to 0 , except the variables Basis $_{0, i, t}^{\text {banking }}$ to Basis $_{3, i, t}^{\text {banking }}$, to make the hazard plots) to facilitate the comparison of hazard plots across further specifications and samples. ${ }^{15)}$

These hazard plots confirm the main findings of Bouvatier (2017). The probability of having a new banking crisis is higher than average (normalized at 0.50 in Figure 1): (i) over the two decades following a banking crisis and (ii) following a long period without any banking crisis. Then, the absence of graduations from banking crises, documented by Reinhart and Rogoff (2008, 2009) and Qian et al. (2011), is supported by Figure 1-a, wherein higher probabilities of falling into crisis are observed when long durations without a crisis are reached because

14) The AUROC curve (also called the concordance statistic or C-index) is equivalent to the probability that the model will rank a randomly chosen crisis period higher than a randomly chosen non-crisis period. Realistic values for the AUROC curve range from 0.5 (random ranking) to 1 (perfect ranking).

15) The covariates (except the variables Basis $_{0, i, t}^{\text {banking }}$ to Basis $_{3, i, t}^{\text {banking }}$ ) could have been set at their sample means or medians to make the hazard plots so that the average probability would have been close to the unconditional probability of a banking crisis (i.e., 0.0334 in the baseline sample) rather than 0.50 . The main advantage of the normalization at 0.50 is that the hazard rate is not sample-dependent, contrary to the unconditional probability of a banking crisis. 
this situation is unlikely to continue, that is, no country succeeded in avoiding banking crises in the long run. The hazard function does not reflect an immutable law of nature but captures the following descriptive feature: over the banking history covered by the estimates, a wide variety of structural and cyclical factors led to the recurrence of banking crises.

The estimate obtained with the more restrictive selection rule (i.e., column (5) of Table 1) is also used for a robustness check to assess the shape of the time-dependence effect in Figure 1-c.16) The more restrictive selection rule does not modify the shape of the hazard function. Nevertheless, Figure 1-c exhibits stronger evidence against graduation from banking crises, as the longest crisis-free interval decreases to 107 years and the slope of the hazard function is steeper in Figure 1-c than in Figure 1-a for crisis-free intervals that exceed four decades.

The shape of the hazard plot reported on Figure 1-a was used as a baseline. The following investigations assessed whether a subset of countries might be characterized by a hazard plot with a different pattern.

Figure 1. Time dependence in banking crises: baseline specification
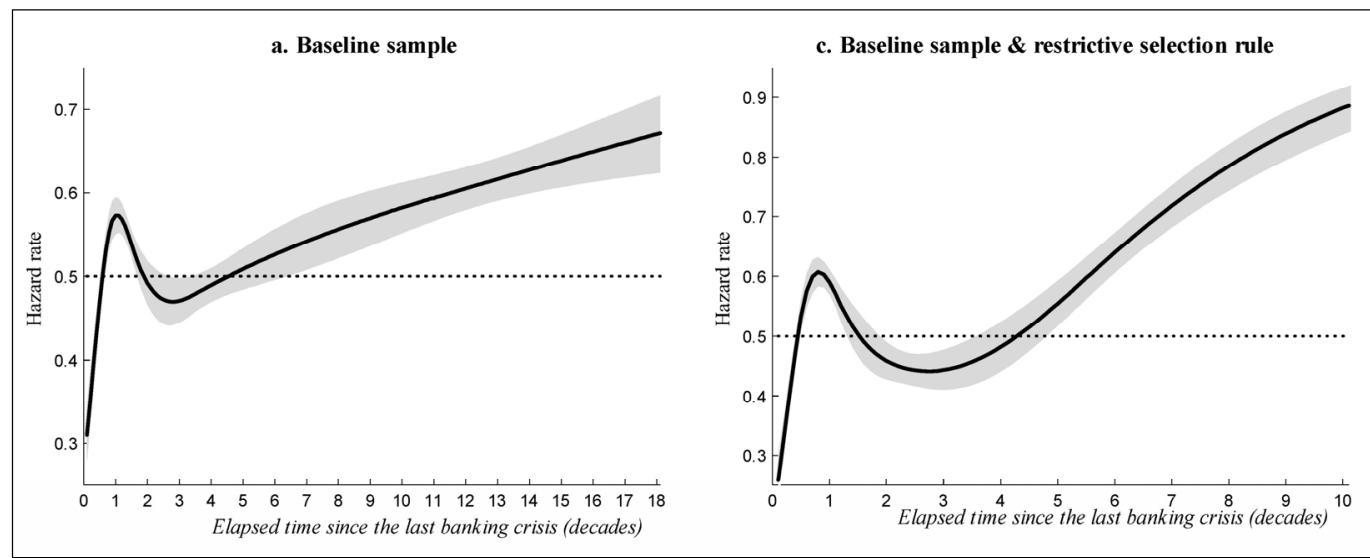

(Note) the grey area corresponds to the one-standard error band

\section{B. Hazard plots and advanced economies}

The estimates of Equation (2) are reported in columns (1) and (2) of Table 2 for the baseline sample and the small sample, respectively. These estimates assess whether the pattern of the hazard function differs between the advanced and other economies. The variable $D_{i, t}^{\text {High }}$ is a dummy variable equal to 1 if the GDP per capita variable $\left(G D P_{i, t-1}^{\text {PerCap }}\right)$ is in the 75 th percentile and equal to 0 otherwise. Therefore, the interaction variables $B a s i s_{j, i, t}^{\text {banking }} \times D_{i, t}^{\text {high }}$ capture whether

16) The hazard plots obtained with the small sample (without and with the more restrictive selection rule) are reported in Appendix 3 for a robustness check and display quite similar shapes. 
Table 2. Time dependence and advanced economies

\begin{tabular}{|c|c|c|c|c|c|c|c|c|}
\hline Sample: & \multicolumn{2}{|c|}{$\begin{array}{c}(1) \\
\text { Baseline }\end{array}$} & \multicolumn{2}{|c|}{$\begin{array}{c}(2) \\
\text { Small }\end{array}$} & \multicolumn{2}{|c|}{$\begin{array}{c}(3) \\
\text { Baseline }\end{array}$} & \multicolumn{2}{|c|}{$\begin{array}{c}\text { (4) } \\
\text { Baseline \& restrictive } \\
\text { selection rule }\end{array}$} \\
\hline \multirow[t]{2}{*}{$\begin{array}{l}\text { Criteria to define } \\
\text { the variable } D_{i, t}^{\text {High }}\end{array}$} & \multicolumn{2}{|c|}{$\begin{array}{l}\text { 75th percentile of } \\
\qquad G D P_{i, t-1}^{P_{e r} C a p}\end{array}$} & \multicolumn{2}{|c|}{$\begin{array}{l}\text { 75th percentile of } \\
\qquad G D P_{i, t-1}^{\text {Per Cap }}\end{array}$} & \multicolumn{2}{|c|}{$\begin{array}{l}\text { High-income group } \\
\text { Income } e_{i}^{\text {High }}\end{array}$} & \multicolumn{2}{|c|}{$\begin{array}{c}\text { 75th percentile of } \\
\qquad G D P_{i, t-1}^{\text {PerCap }}\end{array}$} \\
\hline & Coef. & S.E. & Coef. & S.E. & Coef. & S.E. & Coef. & S.E. \\
\hline Share $_{t-1}^{\text {crisis }}$ & $0.0373 * * *$ & $(0.0077)$ & $0.0212^{* * *}$ & $(0.0065)$ & $0.0372 * * *$ & $(0.0077)$ & $0.0192 * *$ & $(0.0085)$ \\
\hline KMobility $_{t}$ & $0.7099 * *$ & $(0.2914)$ & $1.1398^{* * *}$ & $(0.3501)$ & $0.5900 * *$ & $(0.2880)$ & $0.7977 * *$ & $(0.3997)$ \\
\hline Count $_{i, t-1}$ & $0.0694 * * *$ & $(0.0199)$ & 0.0326 & $(0.0220)$ & $0.0680^{* * *}$ & $(0.0203)$ & $0.0715^{* * *}$ & $(0.0220)$ \\
\hline $\operatorname{Period}_{t}^{1800 ~ ~} 1820$ & 0.5954 & $(0.3900)$ & 0.4231 & $(0.4281)$ & 0.4640 & $(0.3687)$ & $1.1817^{* * *}$ & $(0.3504)$ \\
\hline $\operatorname{Period}_{t}^{1821 ~ ~ 1913}$ & $0.4439 * *$ & $(0.1969)$ & 0.3130 & $(0.2059)$ & 0.3085 & $(0.1935)$ & $0.8484 * * *$ & $(0.2311)$ \\
\hline $\operatorname{Period}_{t}^{1914 \sim 1945}$ & $0.8225^{* * *}$ & $(0.2757)$ & $0.8991 * * *$ & $(0.2942)$ & $0.6396^{* *}$ & $(0.2643)$ & $1.2291 * * *$ & $(0.3269)$ \\
\hline $\operatorname{Period}_{t}^{1946 \sim 1972}$ & $-2.3982 * * *$ & $(0.6185)$ & $-2.3402 * * *$ & $(0.6461)$ & $-2.4671^{* * *}$ & $(0.6091)$ & $-2.0554 * * *$ & $(0.7505)$ \\
\hline$G D P_{i, t-1}^{\text {Per Cap }}$ & 0.1060 & $(0.1133)$ & 0.0804 & $(0.1318)$ & 0.0982 & $(0.0777)$ & 0.0869 & $(0.1068)$ \\
\hline Inflation $_{i, t-1}$ & $0.0058^{* * *}$ & $(0.0010)$ & $0.0070^{* * *}$ & $(0.0011)$ & $0.0058^{* * *}$ & $(0.0010)$ & $0.0054 * * *$ & $(0.0015)$ \\
\hline$D_{i, t}^{H i g h}$ & -0.0103 & $(0.2353)$ & -0.0696 & $(0.2414)$ & 0.1056 & $(0.1867)$ & -0.1399 & $(0.2362)$ \\
\hline Intercept & $-4.3784 * * *$ & $(0.2368)$ & $-4.2778 * * *$ & $(0.2817)$ & $-4.2611^{* * *}$ & $(0.2203)$ & $-4.5643^{* * *}$ & $(0.3436)$ \\
\hline Basis $_{0, i, t}^{\text {banking }}$ & 0.0865 & $(0.0628)$ & -0.0111 & $(0.0709)$ & $0.1484 * *$ & $(0.0658)$ & 0.1408 & $(0.1258)$ \\
\hline Basis $_{1, i, t}^{\text {banking }}$ & -0.0475 & $(0.0831)$ & -0.0775 & $(0.0998)$ & 0.0360 & $(0.0807)$ & $-0.1466^{*}$ & $(0.0844)$ \\
\hline $\operatorname{Basis}_{2, i, t}^{\text {banking }}$ & $-0.2005 * * *$ & $(0.0680)$ & $-0.2178 * * *$ & $(0.0725)$ & $-0.1670 * *$ & $(0.0759)$ & $-0.3276 * * *$ & $(0.0892)$ \\
\hline Basis $_{3, i, t}^{\text {banking }}$ & -0.0015 & $(0.0693)$ & 0.0211 & $(0.0965)$ & -0.0059 & $(0.0852)$ & 0.1492 & $(0.1082)$ \\
\hline Basis $_{0, i, t}^{\text {banking }} \times D_{i, t}^{\text {High }}$ & $0.3657^{* * *}$ & $(0.1161)$ & $0.4148 * * *$ & $(0.0983)$ & 0.2742 & $(0.2309)$ & 0.2210 & $(0.1621)$ \\
\hline Basis $_{1, i, t}^{\text {banking }} \times D_{i, t}^{\text {High }}$ & 0.0496 & $(0.1449)$ & 0.0826 & $(0.1571)$ & -0.2039 & $(0.1705)$ & 0.2044 & $(0.1613)$ \\
\hline Basis $_{2, i, t}^{\text {banking }} \times D_{i, t}^{\text {High }}$ & -0.1204 & $(0.1265)$ & 0.0080 & $(0.1325)$ & -0.1533 & $(0.1190)$ & -0.2112 & $(0.1566)$ \\
\hline Basis $_{3, i, t}^{\text {banking }} \times D_{i, t}^{\text {High }}$ & $0.2768^{* *}$ & $(0.1199)$ & $0.3261 * *$ & $(0.1434)$ & 0.2060 & $(0.1303)$ & $-0.2710^{*}$ & $(0.1609)$ \\
\hline Log-likelihood & -1371.72 & & -1080.01 & & -1373.70 & & -865.38 & \\
\hline Pseudo $R^{2}$ & 0.0681 & & 0.0817 & & 0.0668 & & 0.0777 & \\
\hline AUROC curve & 0.7154 & & 0.7296 & & 0.7145 & & 0.7227 & \\
\hline $\begin{array}{l}\text { AUROC test } \\
{[p \text {-value }]}\end{array}$ & $\begin{array}{c}3.04 \\
{[0.0813]}\end{array}$ & & $\begin{array}{c}4.07 \\
{[0.0435]}\end{array}$ & & $\begin{array}{c}3.91 \\
{[0.0480]}\end{array}$ & & $\begin{array}{c}0.49 \\
{[0.4832]}\end{array}$ & \\
\hline $\begin{array}{l}\text { LR test } \\
\qquad[p \text {-value }]\end{array}$ & $\begin{array}{c}11.65 \\
{[0.0400]}\end{array}$ & & $\begin{array}{c}12.37 \\
{[0.0300]}\end{array}$ & & $\begin{array}{c}7.10 \\
{[0.1305]}\end{array}$ & & $\begin{array}{c}9.83 \\
{[0.0802]}\end{array}$ & \\
\hline No. obs. & 10047 & & 7424 & & 10047 & & 5786 & \\
\hline No. countries & 148 & & 70 & & 148 & & 123 & \\
\hline No. crises & 336 & & 275 & & 336 & & 221 & \\
\hline
\end{tabular}

the hazard function is different for the advanced economies.

In columns (1) and (2) of Table 2, two coefficients associated with the interaction variables are significant at the $1 \%$ or $5 \%$ level. Moreover, the LR and the AUROC tests reported in columns 
(1) and (2) of Table 2 assess whether the set of four interaction variables does not significantly increase the likelihoods and the AUROC curves, respectively. The null hypotheses are not supported at the $10 \%$ level. Therefore, the first results suggest that the hazard plot characterizing the advanced economies is significantly different from the one characterizing the other economies.

For a robustness check, we first modified the definition of the variable $D_{i, t}^{h i g h}$. We used the category of high-income countries as criteria to identify the advanced economies. In column (3) of Table 2, the variable $D_{i, t}^{\text {high }}$ is a dummy variable equal to 1 if country $i$ is classified as high income and equal to 0 otherwise. The four interaction variables are not significant at the $10 \%$ level. In column (3) of Table 2, the LR test logically concludes at the $10 \%$ level that the introduction of the set of four interaction variables does not significantly improve likelihood, while the AUROC test still suggests that the interaction variables increase the ranking power of the model at the $5 \%$ level.

Equation (2) was also estimated with the more restrictive selection rule that kept only independent countries that had already faced a banking crisis in the samples. According to the estimate reported in column (4) of Table 2, only one interaction variable is significant at the $10 \%$ level. Furthermore, the set of interaction variables increases the likelihood at the $10 \%$ level according to the LR test, while the ranking power of the model is not improved at the $10 \%$ level according to the AUROC test.

Therefore, not all the estimates reported in Table 2 lead to strong and robust statistical evidence indicating that the time-dependence effect differs between the advanced and other economies. To explicitly illustrate how the shape of the hazard plots differs between the advanced and other economies, the hazard plots generated from the estimates reported in columns (1), (3), and (4) of Table 2 are displayed in Figures 2-a, 2-b, and 2-c, respectively. ${ }^{17)}$ The first finding is that, in line with the previous mixed results, the shape of the hazard function is not extremely different between the advanced and other economies. Focusing on Figures 2-a and 2-b, the changes are more pronounced for the advanced economies; however, as the number of periods without a banking crisis increases, we observe that exposure to a new banking crisis is increasing regardless of the economic development level. The risk of recidivism is faster to materialize solely in the advanced economies.

However, Figure 2-c suggests that this difference is mainly driven by countries that had not faced a banking crisis yet. Indeed, when the more restrictive selection rule that excludes these countries is considered, Figure 2-c shows that changes in the hazard functions are quite similar between the advanced and other economies. Second, in Figure 2-a and, especially, Figures 2-b and 2-c, we observe that the longer durations without a banking crisis have not

17) For a robustness check, we also estimated the model for the sub-sample of high-income countries (Appendix 9, columns (1) and (4)), and the hazard plots are displayed in Appendix 10. We obtained similar hazard plots for advanced economies when the sub-sample was considered. 
been recorded by the advanced economies. ${ }^{18)}$ This difference, not captured by the estimates reported in Table 2, provides a more convincing insight on the fact that the risk of recidivism is faster to materialize only in advanced economies.

Figure 2. Hazard plots and advanced economies

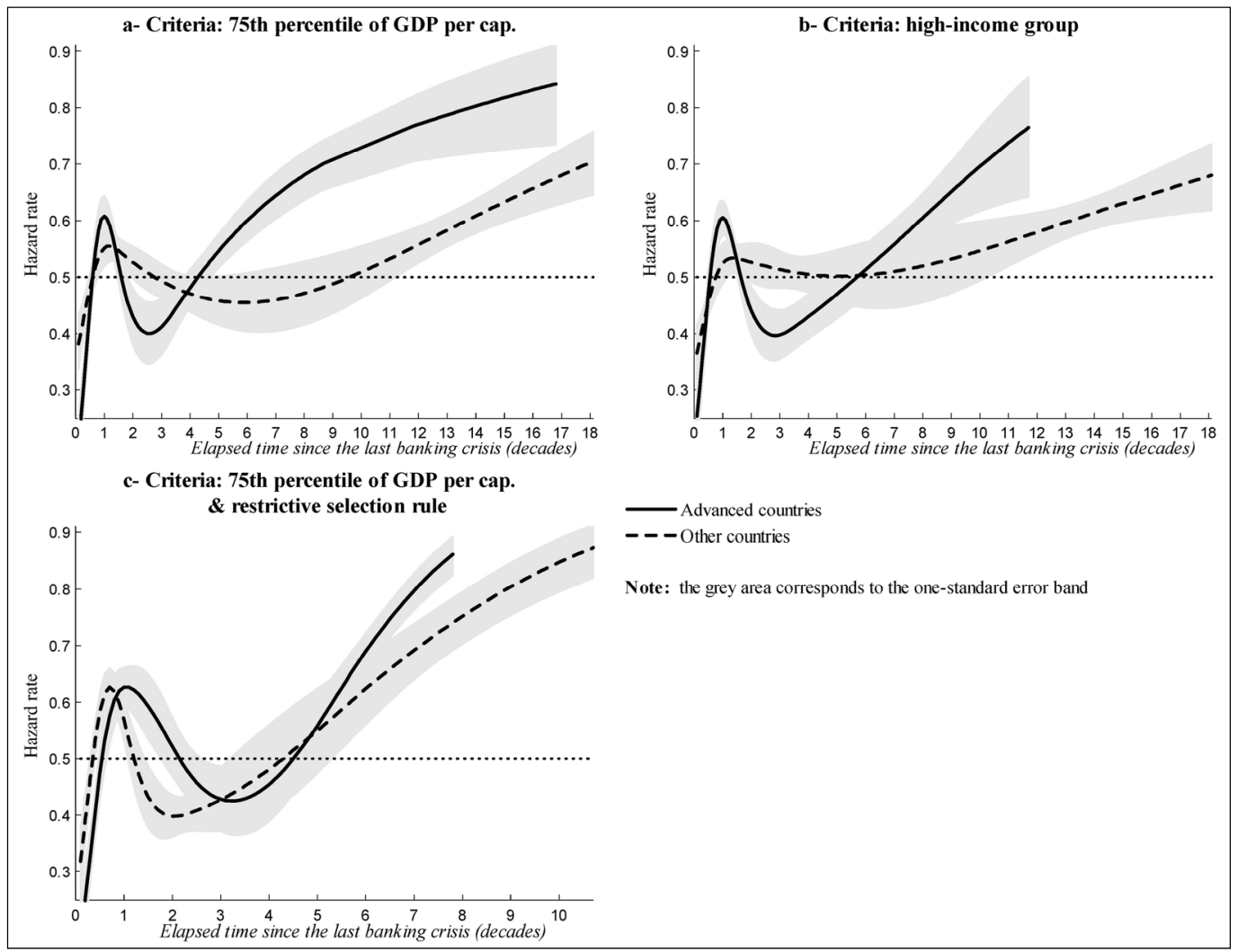

Therefore, depending on both the criteria used to identify the advanced economies and the sample, we found statistical differences between the time-dependence effect in between the advanced and other economies. More importantly, however, the shapes of the hazard functions never exhibited substantial disparities in the risk of recidivism. Another conclusion that we reached from the first results is that the economic development level assessed from GDP per capita or the income groups might not be the most obvious criterion to differentiate the degree of exposure to a banking crisis. Countries with the longest durations without a banking crisis in the sample are mainly countries that remained on the periphery of the international financial system for a long time. This situation can reduce exposure to the different categories of financial

18) For example, the four countries with the longest durations without a banking crisis in the baseline sample are Thailand (181 years), Honduras (179 years), Colombia (173 years), and Guatemala (170 years). 
crises. Therefore, we investigated whether exposure to non-banking financial crises and the status of international banking centers are the evident criteria to differentiate the degree of exposure to a banking crisis.

\section{The influence of non-banking financial crises}

The databases provided by Reinhart (2010) and Laeven and Valencia (2013) cover more than banking crises. The Reinhart (2010) database includes currency, external debt, and inflation crises while the Laeven and Valencia (2013) database includes currency and external debt crises.

Reinhart and Rogoff (2008, 2009) and Qian et al. (2011) concluded from the comparison of these different types of financial crises that advanced economies seem to have graduated from default and inflation crises, but no country has graduated from banking crises. This conclusion should imply that the occurrence of banking crises does not depend on the occurrence of non-banking financial crises. In other words, countries that have graduated from default and inflation crises do not necessarily benefit from lower exposure to banking crises. However, the literature on financial crises can pose a challenge to this implication. For instance, a chain of causation can run from inflation or default crises to banking crises (Friedman \& Schwartz 1963, Balderston 1991, Demirgüç-Kunt \& Detragiache 1998, BIS 2011).

The estimates provided by Equation (3) with the baseline sample are reported in Table 3. These estimates assess whether countries prone to non-banking financial crises face a higher risk of recidivism of banking crises. In column (1) of Table 3, we include the variables Basis $j_{j, i, t}^{\text {currency }}$ corresponding to the basis variables of a spline function computed from the durations between currency crises. This set of variables assesses whether the duration since the last currency crisis affects the occurrence of a new banking crisis. Column (2) of Table 3 shows the same exercise run while considering the variables Basis $s_{j, i, t}^{\text {debt }}$ computed from the durations between external debt crises. Simultaneously, in the last column, we include the variables Basis $s_{j, i, t}^{\text {currency }}$ and Basis $j_{j, i, t}$. Inflation crises will only be included later because this category of crisis is only available in the Reinhart (2010) database, i.e., for the small sample and not for the baseline sample.

First, in Table 3, we observe that expanding the baseline specification does not significantly modify the previous results. In particular, the coefficients associated with the variables Basis $s_{j, i, t}^{\text {banking }}$ do not noticeably differ. Second, column (1) of Table 3 shows that exposure to a banking crisis is influenced by the occurrence of currency crises. The variables Basis $s_{0, i, t}^{\text {currency }}$ and Basis $s_{2, i, t}^{\text {currency }}$ are significant at the $5 \%$ level. Moreover, the LR and AUROC tests conclude that the set of variables Basis ${ }_{j, i, t}^{\text {currency }}$ significantly increases the likelihood at the $1 \%$ level and the AUROC curve at the $10 \%$ level, respectively. However, a graphical analysis is required to evaluate how the time elapsed since the last currency crisis modifies the shape of the hazard function characterizing 
Table 3. Effects of currency and external debt crises on banking crises

\begin{tabular}{|c|c|c|c|c|c|c|}
\hline Sample: & \multicolumn{2}{|c|}{$\begin{array}{c}(1) \\
\text { Baseline }\end{array}$} & \multicolumn{2}{|c|}{$\begin{array}{c}(2) \\
\text { Baseline }\end{array}$} & \multicolumn{2}{|c|}{$\begin{array}{c}(3) \\
\text { Baseline }\end{array}$} \\
\hline \multirow[t]{2}{*}{ Non-banking Crisis $(K)$ : } & \multicolumn{2}{|c|}{$K=$ currency } & \multicolumn{2}{|c|}{$K=d e b t$} & \multicolumn{2}{|c|}{$K=$ currency, debt } \\
\hline & Coef. & S.E. & Coef. & S.E. & Coef. & S.E. \\
\hline Share $_{t-1}^{\text {crisis }}$ & $0.0340^{* * *}$ & $(0.0076)$ & $0.0374 * * *$ & $(0.0077)$ & $0.0341 * * *$ & $(0.0077)$ \\
\hline KMobility $_{t}$ & $0.8098^{* * *}$ & $(0.2932)$ & $0.6344 * *$ & $(0.2938)$ & $0.7800 * * *$ & $(0.2942)$ \\
\hline Count $_{i, t-1}$ & $0.0519 * * *$ & $(0.0190)$ & $0.0580 * * *$ & $(0.0192)$ & $0.0432 * *$ & $(0.0196)$ \\
\hline $\operatorname{Period}_{t}^{1800 ~ ~} 1820$ & 0.5067 & $(0.3846)$ & 0.4972 & $(0.3728)$ & 0.5017 & $(0.3879)$ \\
\hline $\operatorname{Period}_{t}^{1821 ~ ~} 1913$ & $0.5057 * * *$ & $(0.1691)$ & 0.2013 & $(0.1761)$ & $0.3935^{* *}$ & $(0.1637)$ \\
\hline $\operatorname{Period}_{t}^{1914 \sim 1945}$ & $0.7644 * * *$ & $(0.2537)$ & $0.6348 * *$ & $(0.2595)$ & $0.7109 * * *$ & $(0.2524)$ \\
\hline Period $_{t}^{1946 ~ ~ 1972}$ & $-2.4466 * * *$ & $(0.6122)$ & $-2.5694 * * *$ & $(0.6089)$ & $-2.5151 * * *$ & $(0.6121)$ \\
\hline$G D P_{i, t-1}^{\text {PerCap }}$ & $0.1509 * *$ & $(0.0673)$ & 0.1015 & $(0.0775)$ & 0.1082 & $(0.0796)$ \\
\hline Inflation $_{i, t-1}$ & $0.0047 * * *$ & $(0.0010)$ & $0.0057^{* * *}$ & $(0.0010)$ & $0.0046^{* * *}$ & $(0.0011)$ \\
\hline Intercept & $-4.3958 * * *$ & $(0.2079)$ & $-4.2276 * * *$ & $(0.2027)$ & $-4.3261 * * *$ & $(0.2031)$ \\
\hline Basis $_{0, i, t}^{\text {banking }}$ & $0.1781 * * *$ & $(0.0503)$ & $0.1647 * * *$ & $(0.0545)$ & $0.1739 * * *$ & $(0.0591)$ \\
\hline Basis $_{1, i, t}^{\text {banking }}$ & 0.0339 & $(0.0586)$ & 0.0571 & $(0.0592)$ & 0.0477 & $(0.0615)$ \\
\hline Basis $_{2, i, t}^{\text {banking }}$ & $-0.2479 * * *$ & $(0.0548)$ & $-0.2383 * * *$ & $(0.0536)$ & $-0.2587 * * *$ & $(0.0541)$ \\
\hline Basis ${ }_{3, i, t}^{\text {banking }}$ & 0.1059 & $(0.0590)$ & 0.0725 & $(0.0666)$ & 0.0665 & $(0.0653)$ \\
\hline Basis $_{0, i, t}^{\text {currency }}$ & $-0.1841^{* *}$ & $(0.0855)$ & & & $-0.2074^{* *}$ & $(0.0814)$ \\
\hline Basis $_{1, i, t}^{\text {currency }}$ & -0.1088 & $(0.0675)$ & & & -0.0712 & $(0.0644)$ \\
\hline Basis $_{2, i, t}^{\text {currency }}$ & $0.1638 * *$ & $(0.0653)$ & & & $0.1685^{* *}$ & $(0.0686)$ \\
\hline Basis $_{3, i, t}^{\text {currency }}$ & 0.0006 & $(0.0635)$ & & & -0.0077 & $(0.0620)$ \\
\hline Basis $_{0, i, t}^{\text {debt }}$ & & & 0.0452 & $(0.0714)$ & 0.0843 & $(0.0701)$ \\
\hline Basis $s_{1, i, t}^{\text {debt }}$ & & & 0.0008 & $(0.0584)$ & 0.0255 & $(0.0587)$ \\
\hline Basis $_{2, i, t}^{\text {debt }}$ & & & 0.1100 & $(0.0637)$ & 0.0777 & $(0.0648)$ \\
\hline Basis $_{3, i, t}^{\text {debt }}$ & & & 0.1531 & $(0.0734)$ & $0.1553^{* *}$ & $(0.0717)$ \\
\hline Log-likelihood & -1366.75 & & -1372.31 & & -1361.62 & \\
\hline Pseudo $R^{2}$ & 0.0715 & & 0.0677 & & 0.0750 & \\
\hline AUROC curve & 0.7161 & & 0.7129 & & 0.7242 & \\
\hline $\begin{array}{l}\text { AUROC test } \\
{[p \text {-value }]}\end{array}$ & $\begin{array}{c}3.02 \\
{[0.0821]}\end{array}$ & & $\begin{array}{c}1.48 \\
{[0.2240]}\end{array}$ & & $\begin{array}{c}6.87 \\
{[0.0087]}\end{array}$ & \\
\hline $\begin{array}{l}\text { LR test } \\
\qquad[p \text {-value }]\end{array}$ & $\begin{array}{c}21.59 \\
{[0.0002]}\end{array}$ & & $\begin{array}{c}10.47 \\
{[0.0332]}\end{array}$ & & $\begin{array}{c}31.85 \\
{[0.0001]}\end{array}$ & \\
\hline No. obs. & 10047 & & 10047 & & 10047 & \\
\hline No. countries & 148 & & 148 & & 148 & \\
\hline No. crises & 336 & & 336 & & 336 & \\
\hline
\end{tabular}

(Note) $* * * * *$ and $*$ indicate significance respectively at the $1 \%, 5 \%$ and $10 \%$ levels. Cluster robust standard deviations are in brackets. The null hypothesis of the LR test is that the likelihoods are equal in the specifications with and without the basis variables associated with non-banking financial crises. The null hypothesis of the AUROC test is that the AUROC curves are equal in the specifications with and without the basis variables associated with non-banking financial crises. 
banking crises. Third, the occurrence of external debt crises seems less relevant. In column (2) of Table 3, the variables Basis $s_{2, i, t}^{\text {debt }}$ and Basis $_{3, i, t}^{\text {debt }}$ are significant at the $10 \%$ and $5 \%$ levels, respectively. However, the AUROC test indicates that the set of variables Basis $s_{j, i, t}^{\text {debt }}$ does not significantly improve the ranking power of the model at the $10 \%$ level. Furthermore, the variable Basis $_{2, i, t}^{\text {debt }}$ turns insignificant at the $10 \%$ level in column (3) when currency and external debt crises are simultaneously considered in the specification. For a robustness check, Equation (3) is also estimated with the restrictive selection rule. Similarly, it is concluded that only the variables Basis currency $_{j, t}$ matter for the model specification. ${ }^{19)}$

Figure 3 displays the hazard functions obtained from the estimate reported in column (3) of Table 3. In Figure 3-a, the variables Basis ${ }_{j, i, t}^{\text {currency }}$ and Basis ${ }_{j, i, t}^{\text {debt }}$ are set to 0 as are all the other covariates, except the variable Basis $_{j, i, t}^{\text {banking }}$. Thus, Figure 3-a displays the standard hazard function characterizing banking crises in line with the results discussed in subsection IV-A. Figure 3-b introduces a third dimension, that is, the time elapsed since the last currency crisis. ${ }^{20)}$ Therefore, Figure 3-b shows how the hazard function characterizing banking crises changes when the time elapsed since the last currency crisis increases, that is, when the country is no longer prone to currency crises.

Figure 3-b shows two important results. First, for a given value of the $x$-axis, the hazard rate is particularly high when the time elapsed since the last currency crisis is 0 (i.e., when the country is already in currency crisis), or significantly close to 0 (i.e., in a post-currency crisis period). This result captures the chain of causation that runs from currency to banking crises, as suggested by Stoker (1995). Thus, even if the main causal chain runs from banking to currency crises according to the existing literature (Kaminsky \& Reinhart 1999, Glick \& Hutchison 1999, Eichengreen \& Arteta 2000), we identified that countries in a currency crisis since (at least) the previous period, and countries in a post-currency crisis period face a higher risk of falling into a banking crisis. ${ }^{21)}$ Among the 336 banking crisis events covered by the baseline sample, almost 30 events occurred when the country was already in a currency crisis and more than 20 additional events occurred in the two years following a currency crisis.

Second, Figure 3-b shows that the surface decreases when we move along the $y$-axis. Exposure to a banking crisis and, thus, the risk of recidivism in a banking crisis declines when the country is no longer concerned with a currency crisis. In other words, countries that had not faced

19) The estimates obtained with the restrictive selection rule are reported in Appendix 5.

20) The $x$-axis is the time elapsed since the last banking crisis; the $y$-axis is the time elapsed since the last currency crisis; and the $z$-axis is the hazard rate.

21) The causal chain that runs from banking crises to currency crises was not investigated in this paper. Such an investigation would require us to specify a model that determines the risk of currency crises. We only focused on the risk of banking crises in this paper. Multivariate approaches based on multivariate logit models have been considered, for instance, by Falcetti and Tudela (2008) for the analysis of banking and currency crises or by Reinhart and Rogoff (2011) for the analysis of banking and debt crises. 
any currency crises for more than a century, for instance, had a lower probability of facing a new banking crisis than countries that frequently faced currency crises, regardless of the duration since the last banking crisis. This result suggests that economic environments that make countries more prone to currency crises also increase exposure to a new banking crisis because these two categories of crises share a chain of causation and can be interdependent. However, Figure 4-a suggests that this result is mainly driven by countries that have not yet faced a banking crisis. When the restrictive selection rule was considered, the surface was rather flat along the $y$-axis (except for currency crisis and post-currency crisis periods). In other words, economic environments that make countries more prone to currency crises affect the occurrence of the first banking crisis.

In Figures 3-c and 4-b, a similar approach was used (without and with the restrictive selection rule, respectively), but the third dimension is now the time elapsed since the last external debt crisis. As expected, the surface is relatively flat when moving along the $y$-axis. The time elapsed since the last external debt crisis does not disturb the shape and the level of the hazard function much. The absence of a monotonic change of the hazard function along the $y$-axis (i.e., when the time since the last debt crisis is increasing) might have been expected because the coefficients associated with the variables Basis $_{j, i, t}^{d e b t}$ reported in Table 3 are weakly or not significant.

Figure 3. The influence of non-banking financial crises: baseline sample

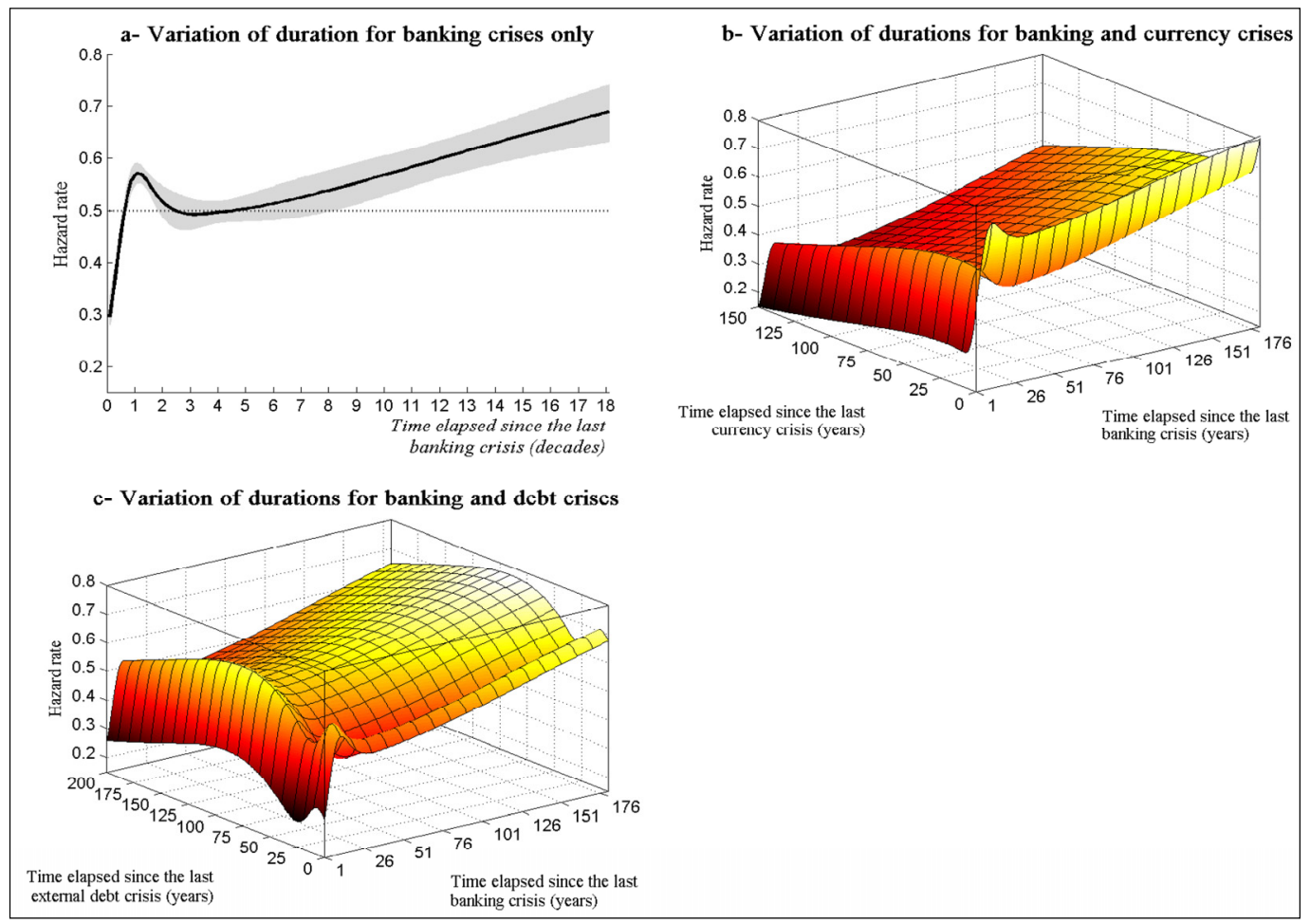


Figure 4. The influence of non-banking financial crises: restrictive selection rule

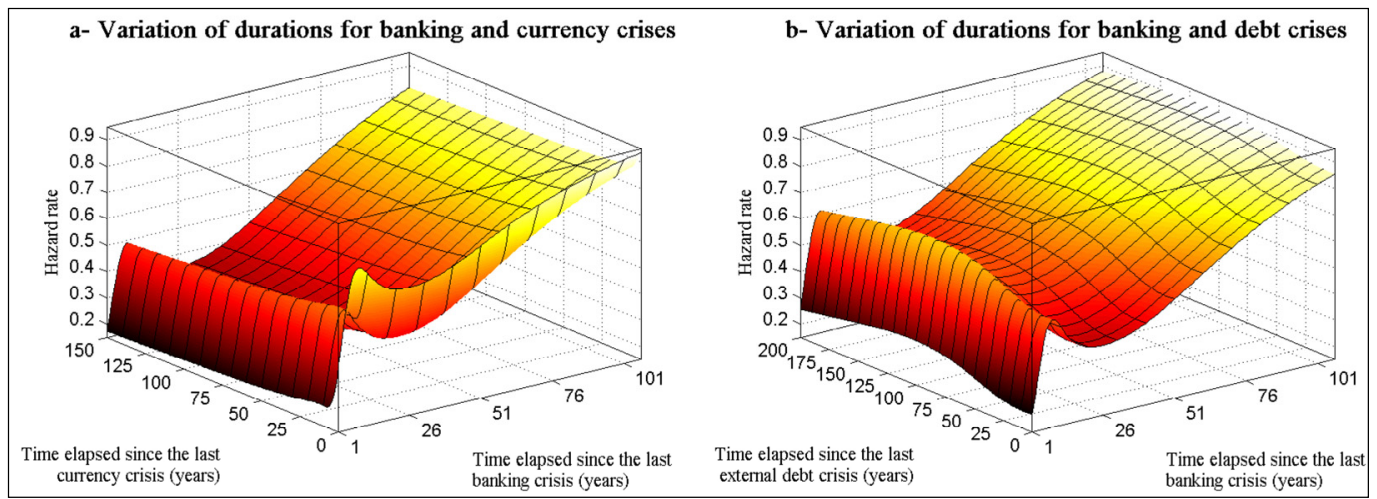

For a robustness check, the same specifications were estimated with the small sample. Moreover, the small sample was used to introduce inflation crises because this category of crises is only available in the Reinhart (2010) database. The estimates are reported in Table 4, and Figure 5 displays the hazard plots. Concerning the effect of currency and external debt crises, the previous results seem robust when the small sample is considered. In Figures 5-a and 5-b, the displayed hazard plots highlight the effects of currency crises and external debt crises, respectively, and are quite similar to the ones in Figure 3. However, the identification of this relationship is weaker in the small sample than in the baseline sample. In column (1) of Table 4, only one of the variables Basis $_{j, i, t}^{\text {currency }}$ is significant at the $5 \%$ level, and the AUROC test indicates that the predictive power of the model is not significantly improved at the $10 \%$ level. Furthermore, regarding external debt crises, the LR and the AUROC tests in column (2) of Table 4 and Figure 5-b confirm that graduation in debt crises does not noticeably affect exposure to a banking crisis. The surface is relatively flat along the $y$-axis, indicating that countries recording more than a century without an external debt crisis do not benefit from lower exposure to a banking crisis than countries recording an external debt crisis in the last decade (all other things being equal).

Finally, Figure 5-c provides an insight into the effect of inflation crises on exposure to a banking crisis. For a given value of the $x$-axis, the hazard rate is particularly high when the time elapsed since the last inflation crisis is lower than a decade. This result indicates that inflation crises make countries prone to banking crises, which is in line with both the existing literature (Friedman \& Schwartz 1963, Balderston 1991, Demirgüç-Kunt \& Detragiache 1998) and with the positive and significant effect at the $1 \%$ level of the control variable Inflation $_{i, t-1}$. When the time elapsed since the last inflation crisis becomes larger than a decade, Figure 5-c shows that the surface is almost flat along the $y$-axis. Therefore, graduation from inflation crises does not continue to reduce exposure to a banking crisis. 
Table 4. Effects of currency, external debt and inflation crises on banking crises

\begin{tabular}{|c|c|c|c|c|c|c|c|c|}
\hline Sample: & \multicolumn{2}{|c|}{$\begin{array}{c}(1) \\
\text { Baseline }\end{array}$} & \multicolumn{2}{|c|}{$\begin{array}{c}(2) \\
\text { Small }\end{array}$} & \multicolumn{2}{|c|}{$\begin{array}{c}(3) \\
\text { Baseline }\end{array}$} & \multicolumn{2}{|c|}{$\begin{array}{c}\text { (4) } \\
\text { Baseline \& restrictive } \\
\text { selection rule }\end{array}$} \\
\hline \multirow[t]{2}{*}{ Non-banking crisis: } & \multicolumn{2}{|c|}{$K=$ currency } & \multicolumn{2}{|c|}{$K=d e b t$} & \multicolumn{2}{|c|}{$K=$ Inflation } & \multicolumn{2}{|c|}{$K=$ curr., debt, inflat. } \\
\hline & Coef. & S.E. & Coef. & S.E. & Coef. & S.E. & Coef. & S.E. \\
\hline Share $e_{t-1}^{\text {crisis }}$ & $0.0189 * * *$ & $(0.0065)$ & $0.0218 * * *$ & $(0.0064)$ & $0.0196^{* * *}$ & $(0.0067)$ & $0.0181 * * *$ & $(0.0066)$ \\
\hline KMobility $_{t}$ & $1.1682 * * *$ & $(0.3465)$ & $0.9551 * * *$ & $(0.3445)$ & $1.1992 * * *$ & $(0.3782)$ & $1.2560^{* * *}$ & $(0.3509)$ \\
\hline Count $_{i, t-1}$ & 0.0246 & $(0.0216)$ & 0.0269 & $(0.0215)$ & 0.0338 & $(0.0215)$ & 0.0257 & $(0.0220)$ \\
\hline $\operatorname{Period}_{t}^{1800 ~ ~ 1820}$ & 0.4039 & $(0.4098)$ & 0.4404 & $(0.4428)$ & 0.2702 & $(0.4141)$ & 0.4619 & $(0.4596)$ \\
\hline $\operatorname{Period}_{t}^{1821 \sim 1913}$ & $0.3305^{*}$ & $(0.1811)$ & 0.0805 & $(0.1788)$ & 0.2070 & (0.1999) & 0.2450 & $(0.1911)$ \\
\hline Period $_{t}^{1914 \sim 1945}$ & $0.8093 * * *$ & $(0.2668)$ & $0.6606 * *$ & $(0.2572)$ & $0.7437^{* *}$ & $(0.2940)$ & $0.7691 * * *$ & $(0.2664)$ \\
\hline Period $_{t}^{1946 ~ ~ 1972}$ & $-2.4215^{* * *}$ & $(0.6337)$ & $-2.5445^{* * *}$ & $(0.6238)$ & $-2.4571 * * *$ & $(0.6428)$ & $-2.4082 * * *$ & $(0.6386)$ \\
\hline$G D P_{i, t-1}^{\text {Per Cap }}$ & 0.0891 & $(0.0800)$ & 0.0247 & $(0.0895)$ & $0.1408^{*}$ & $(0.0843)$ & 0.0797 & $(0.0920)$ \\
\hline In $_{\text {flation }_{i, t-1}}$ & $0.0056^{* * *}$ & $(0.0014)$ & $0.0073 * * *$ & $(0.0012)$ & $0.0065^{* * *}$ & $(0.0014)$ & $0.0061 * * *$ & $(0.0016)$ \\
\hline Intercept & $-4.2802 * * *$ & $(0.2519)$ & $-4.0736^{* * *}$ & $(0.2339)$ & $-4.2895 * * *$ & $(0.2693)$ & $-4.3122 * * *$ & $(0.2510)$ \\
\hline Basis $_{0, i, t}^{\text {banking }}$ & $0.1206^{*}$ & $(0.0620)$ & 0.0702 & $(0.0607)$ & $0.1080^{*}$ & $(0.0596)$ & 0.1171 & $(0.0742)$ \\
\hline Basis $_{1, i, t}^{\text {banking }}$ & 0.0020 & $(0.0696)$ & 0.0033 & $(0.0691)$ & 0.0435 & $(0.0741)$ & 0.0189 & $(0.0747)$ \\
\hline Basis $_{2, i, t}^{\text {banking }}$ & $-0.2068 * * *$ & $(0.0612)$ & $-0.2004 * * *$ & $(0.0608)$ & $-0.2123 * * *$ & $(0.0583)$ & $-0.2338^{* * *}$ & $(0.0602)$ \\
\hline Basis $_{3, i, t}^{\text {banking }}$ & $0.1485^{* *}$ & $(0.0708)$ & $0.1454^{*}$ & $(0.0749)$ & $0.1314^{*}$ & $(0.0731)$ & 0.1157 & $(0.0734)$ \\
\hline Basis sarrency $_{0, i, t}^{\text {cur }}$ & $-0.2131^{* *}$ & $(0.1020)$ & & & & & $-0.2053^{*}$ & $(0.1088)$ \\
\hline Basis ${ }_{1, i, t}^{\text {currency }}$ & -0.0333 & $(0.0782)$ & & & & & 0.0006 & $(0.0772)$ \\
\hline Basis $_{2, i, t}^{\text {currency }}$ & 0.1158 & $(0.0748)$ & & & & & $0.1419^{*}$ & $(0.0820)$ \\
\hline Basis $_{3, i, t}^{\text {currency }}$ & 0.0164 & $(0.0740)$ & & & & & 0.0006 & $(0.0711)$ \\
\hline Basis $_{0, i, t}^{\text {debt }}$ & & & 0.0696 & $(0.0813)$ & & & 0.1095 & $(0.0852)$ \\
\hline Basis $_{1, i, t}^{\text {debt }}$ & & & $0.1185^{* *}$ & $(0.0572)$ & & & $0.1512 * *$ & $(0.0613)$ \\
\hline Basis $_{2, i, t}^{\text {debt }}$ & & & 0.0341 & $(0.0662)$ & & & 0.0318 & $(0.0650)$ \\
\hline Basis $_{3, i, t}^{\text {debt }}$ & & & 0.0263 & $(0.0755)$ & & & -0.0046 & $(0.0731)$ \\
\hline Basis $_{0, i, t}^{\infty}{ }^{\infty a l t i o n}$ & & & & & $-0.1790 * * *$ & $(0.0654)$ & $-0.1154^{*}$ & $(0.0645)$ \\
\hline Basis $_{1, i, t}^{\infty \infty a l t i o n}$ & & & & & -0.1371 & $(0.0845)$ & -0.1386 & $(0.0857)$ \\
\hline Basis $_{2, i, t}^{\infty}$ oaltion & & & & & -0.0285 & $(0.0553)$ & -0.0753 & (0.0589) \\
\hline Basis $_{3, i, t}^{\infty o \text { altion }}$ & & & & & $0.1048^{*}$ & $(0.0610)$ & $0.1111^{*}$ & $(0.0598)$ \\
\hline Log-likelihood & -1080.57 & & -1083.73 & & -1080.18 & & -1072.38 & \\
\hline Pseudo $R^{2}$ & 0.0813 & & 0.0786 & & 0.0816 & & 0.0882 & \\
\hline AUROC curve & 0.7244 & & 0.7236 & & 0.7235 & & 0.7357 & \\
\hline $\begin{array}{l}\text { AUROC test } \\
{[p \text {-value }]}\end{array}$ & $\begin{array}{c}2.01 \\
{[0.1565]}\end{array}$ & & $\begin{array}{c}2.43 \\
{[0.1188]}\end{array}$ & & $\begin{array}{c}1.12 \\
{[0.2909]}\end{array}$ & & $\begin{array}{c}7.27 \\
{[0.0070]}\end{array}$ & \\
\hline $\begin{array}{l}\text { LR test } \\
\qquad[p \text {-value }]\end{array}$ & $\begin{array}{c}11.24 \\
{[0.0240]}\end{array}$ & & $\begin{array}{c}4.93 \\
{[0.2942]}\end{array}$ & & $\begin{array}{c}12.03 \\
{[0.0171]}\end{array}$ & & $\begin{array}{c}27.63 \\
{[0.0063]}\end{array}$ & \\
\hline No. obs. & 7424 & & 7424 & & 7424 & & 7424 & \\
\hline No. countries & 70 & & 70 & & 70 & & 70 & \\
\hline No. crises & 275 & & 275 & & 275 & & 275 & \\
\hline
\end{tabular}

(Note) $* * *, * *$ and $*$ indicate significance respectively at the $1 \%, 5 \%$ and $10 \%$ levels. Cluster robust standard deviations are in brackets. The null hypothesis of the LR test is that the likelihoods are equal in the specifications with and without the basis variables associated with non-banking financial crises. The null hypothesis of the AUROC test is that the AUROC curves are equal in the specifications with and without the basis variables associated with non-banking financial crises. 
Figure 5. The influence of non-banking financial crises: small sample

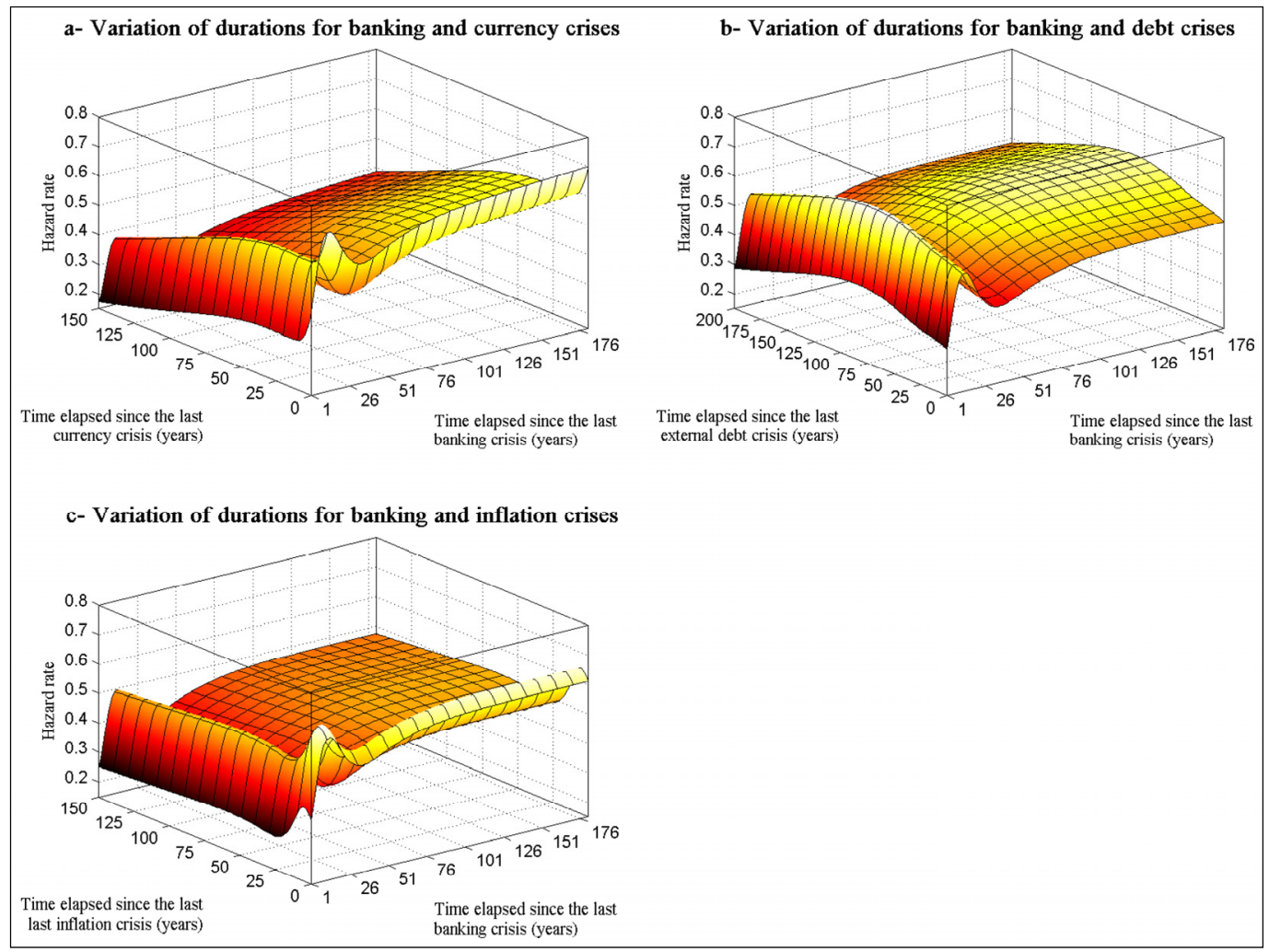

\section{The status of banking center}

The last criterion used to differentiate between countries as regards exposure to banking crises is the hierarchical position in the global banking system. Especially, we use our database of banking centers (see Section II-D) to identify the major banking centers, that is, to define

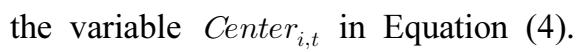

First, the variable Center $_{i, t}$ was defined to identify the top eight countries with major banking centers. These countries generally encompass the global financial centers identified by Reed (1981). ${ }^{22)}$ The estimates of Equation (4) using the baseline sample are reported in column (1) of Table 5. The coefficient associated with the variable Center $_{i, t}$ is significant at the $1 \%$ level.

22) In the baseline sample, 15 different countries have been classified at least during one period as a major banking center (i.e., among the top eight banking centers). These countries are Canada, China, France, Germany, India, Indonesia, Italy, Japan, Netherlands, Russia, Singapore, Spain, Switzerland, United Kingdom, and the United States. Descriptive statistics in Appendix 1 show that these banking centers/observations account for $10.09 \%$ of the baseline sample. Among these observations, only $3.75 \%$ do not belong to the high-income category. However, numerous high-income countries are not classified as top banking centers. Descriptive statistics in Appendix 1 show that high-income countries represent $40.34 \%$ of the baseline sample and concern 39 different countries. 
Table 5. Effect of the banking center status

\begin{tabular}{|c|c|c|c|c|c|c|c|c|}
\hline Sample: & \multicolumn{2}{|c|}{$\begin{array}{c}(1) \\
\text { Baseline }\end{array}$} & \multicolumn{2}{|c|}{$\begin{array}{c}(2) \\
\text { Baseline }\end{array}$} & \multicolumn{2}{|l|}{ line } & \multicolumn{2}{|c|}{$\begin{array}{c}(4) \\
\text { Baseline } \& \text { restrictive } \\
\text { selection rule }\end{array}$} \\
\hline \multirow[t]{2}{*}{$\begin{array}{l}\text { Criteria to define the } \\
\text { variable } \text { Center }_{i, t}\end{array}$} & \multicolumn{2}{|c|}{$\begin{array}{l}\text { Top } 8 \text { banking } \\
\text { centers }\end{array}$} & \multicolumn{2}{|c|}{$\begin{array}{l}\text { Top } 5 \text { banking } \\
\text { centers }\end{array}$} & \multicolumn{2}{|c|}{$\begin{array}{c}\text { Top } 8 \text { banking } \\
\text { centers }\end{array}$} & \multicolumn{2}{|c|}{$\begin{array}{l}\text { Top } 5 \text { banking } \\
\text { centers }\end{array}$} \\
\hline & Coef. & S.E. & Coef. & S.E. & Coef. & S.E. & Coef. & S.E. \\
\hline Share $_{t-1}^{\text {crisis }}$ & $0.0372 * * *$ & $(0.0076)$ & $0.0368 * * *$ & $(0.0078)$ & $0.0194 * *$ & $(0.0088)$ & $0.0191 * *$ & $(0.0089)$ \\
\hline KMobility $_{t}$ & $0.5687 * *$ & $(0.2768)$ & $0.6206^{* *}$ & $(0.2784)$ & $0.8085^{* *}$ & $(0.3813)$ & $0.8120 * *$ & $(0.3808)$ \\
\hline Count $_{i, t-1}$ & $0.0605 * *$ & $(0.0255)$ & $0.0614 * * *$ & $(0.0235)$ & $0.0737 * * *$ & $(0.0263)$ & $0.0730^{* * *}$ & $(0.0242)$ \\
\hline $\operatorname{Period}_{t}^{1800 ~ ~ 1820}$ & 0.4557 & $(0.3364)$ & 0.4815 & $(0.3343)$ & $1.3706^{* * *}$ & $(0.3982)$ & $1.3756^{* * *}$ & $(0.4092)$ \\
\hline $\operatorname{Period}_{t}^{1821 ~ ~ 1913}$ & 0.2711 & $(0.1942)$ & 0.2793 & (0.1964) & $0.8366 * * *$ & $(0.2391)$ & $0.8255 * * *$ & $(0.2422)$ \\
\hline $\operatorname{Period}_{t}^{1914 \sim 1945}$ & $0.6554 * *$ & $(0.2583)$ & $0.6782 * * *$ & $(0.2560)$ & $1.1951^{* * *}$ & $(0.3247)$ & $1.1892 * * *$ & $(0.3247)$ \\
\hline $\operatorname{Period}_{t}^{1946 \sim 1972}$ & $-2.5231 * * *$ & $(0.6069)$ & $-2.5044 * * *$ & $(0.6070)$ & $-2.1186^{* * *}$ & $(0.7218)$ & $-2.1177^{* * *}$ & $(0.7217)$ \\
\hline$G D P_{i, t-1}^{P e r C a p}$ & 0.1045 & $(0.0647)$ & 0.1017 & $(0.0650)$ & 0.0601 & $(0.0688)$ & 0.0558 & $(0.0702)$ \\
\hline In flation $_{i, t-1}$ & $0.0059 * * *$ & $(0.0010)$ & $0.0059 * * *$ & $(0.0010)$ & $0.0057 * * *$ & $(0.0015)$ & $0.0057 * * *$ & $(0.0015)$ \\
\hline Center $_{i, t}$ & $0.7331 * * *$ & $(0.2096)$ & $1.0809^{* *}$ & $(0.4931)$ & -0.0767 & $(0.2301)$ & -0.0674 & $(0.2407)$ \\
\hline Intercept & $-4.2310 * * *$ & $(0.2076)$ & $-4.2558 * * *$ & $(0.2075)$ & $-4.5724 * * *$ & $(0.3461)$ & $-4.5708 * * *$ & $(0.3472)$ \\
\hline Basis $_{0, i, t}^{\text {banking }}$ & $0.1571 * * *$ & $(0.0505)$ & $0.1604 * * *$ & $(0.0489)$ & $0.2245^{* * *}$ & $(0.0856)$ & $0.2129 * * *$ & $(0.0811)$ \\
\hline Basis $_{1, i, t}^{\text {banking }}$ & 0.0295 & $(0.0601)$ & 0.0189 & $(0.0601)$ & -0.0338 & $(0.0796)$ & -0.0514 & $(0.0809)$ \\
\hline Basis $_{2, i, t}^{\text {banking }}$ & $-0.2080 * * *$ & $(0.0596)$ & $-0.1983 * * *$ & $(0.0585)$ & $-0.3676^{* * *}$ & $(0.0636)$ & $-0.3634 * * *$ & $(0.0608)$ \\
\hline Basis $_{3, i, t}^{\text {banking }}$ & $0.1024 *$ & $(0.0616)$ & $0.1010^{*}$ & $(0.0599)$ & 0.0492 & $(0.0739)$ & 0.0587 & $(0.0775)$ \\
\hline Basis $_{0, i, t}^{\text {banking }} \times$ Center $_{i, t}$ & $1.7978 * * *$ & $(0.4850)$ & $2.8691^{*}$ & $(1.5955)$ & 0.0131 & $(0.1362)$ & 0.0990 & $(0.1696)$ \\
\hline Basis $_{1, i, t}^{\text {banking }} \times$ Center $_{i, t}$ & $-1.1218 * * *$ & $(0.3653)$ & -1.6268 & (1.0773) & -0.0017 & $(0.1454)$ & 0.0884 & $(0.1253)$ \\
\hline Basis $_{2, i, t}^{\text {banking }} \times$ Center $_{i, t}$ & $-0.3340^{*}$ & $(0.1769)$ & $-0.5247 *$ & $(0.3044)$ & -0.1536 & $(0.1810)$ & -0.2411 & $(0.2102)$ \\
\hline Basis $_{3, i, t}^{\text {banking }} \times$ Center $_{i, t}$ & -0.1805 & $(0.2196)$ & -0.2252 & $(0.3728)$ & -0.0657 & $(0.2272)$ & -0.1334 & $(0.2264)$ \\
\hline Log-likelihood & -1373.21 & & -1374.83 & & -869.93 & & -869.33 & \\
\hline Pseudo $R^{2}$ & 0.0671 & & 0.0660 & & 0.0729 & & 0.0735 & \\
\hline AUROC curve & 0.7121 & & 0.7092 & & 0.7191 & & 0.7190 & \\
\hline $\begin{array}{l}\text { AUROC test } \\
{[p \text {-value }]}\end{array}$ & $\begin{array}{c}4.66 \\
{[0.0308]}\end{array}$ & & $\begin{array}{c}1.78 \\
{[0.1815]}\end{array}$ & & $\begin{array}{c}0.10 \\
{[0.7528]}\end{array}$ & & $\begin{array}{c}0.01 \\
{[0.9109]}\end{array}$ & \\
\hline $\begin{array}{l}\text { LR test } \\
{[p \text {-value }]}\end{array}$ & $\begin{array}{c}7.21 \\
{[0.1250]}\end{array}$ & & $\begin{array}{c}4.24 \\
{[0.3739]}\end{array}$ & & $\begin{array}{c}0.72 \\
{[0.9495]}\end{array}$ & & $\begin{array}{c}1.93 \\
{[0.7493]}\end{array}$ & \\
\hline No. obs. & 10047 & & 10047 & & 5786 & & 5786 & \\
\hline No. countries & 148 & & 148 & & 123 & & 123 & \\
\hline No. crises & 336 & & 336 & & 221 & & 221 & \\
\hline
\end{tabular}

(Note) $* * * * *$ and $*$ indicate significance respectively at the $1 \%, 5 \%$ and $10 \%$ levels. Cluster robust standard deviations are in brackets. The null hypothesis of the LR test is that the likelihoods are equal in the specifications with and without the 4 interaction variables. The null hypothesis of the AUROC test is that the AUROC curves are equal in the specifications with and without the 4 interaction variables.

Therefore, on average, the status of major banking centers increases the probability of a banking crisis. The specification of Equation (4) also allows us to investigate whether the time-dependence effect differs between major banking centers and the other countries. Some interaction terms 
Basis $_{j, i, t}^{\text {banking }} \times$ Center $_{i, t}$ are significant (i.e., at the $1 \%$ or $10 \%$ level). This result suggests that the hazard plot characterizing banking crises in major banking centers departs from the one observed for the other countries.

However, the LR tests in column (1) of Table 5 indicate that the log-likelihood of the model does not significantly increase at the $10 \%$ level when the interaction terms $\left(\right.$ Basis $_{j, i, t}^{\text {banking }} \times$ Center $\left._{i, t}\right)$ are included in the specification. In column (2) of Table 5, we rely on an alternative definition of major banking centers for a robustness check; the variable Center $r_{i, t}$ identifies the top five banking centers (instead of the top eight). The estimate obtained with this narrow definition of major banking centers confirms that the coefficient associated with the variable Center $r_{i, t}$ is significant (at the 5\% level). Furthermore, column (2) of Table 5 shows that the interaction terms $\left(\right.$ Basis $_{j, i, t}^{\text {banking }} \times$ Center $_{i, t}$ ) are at best weakly significant (at the $10 \%$ level) and indicates that the interaction terms do not significantly increase the log-likelihood of the model at the $10 \%$ level.

The hazard plots associated with columns (1) and (2) of Table 5 are reported in Figures 6-a and 6-b, respectively, to offer a more comprehensive insight into the time-dependence effect identified by the estimates of Equation (4). Over the first decades, the shapes of the hazard functions do not differ significantly between major banking centers and the other countries; the hazard rate increases over the first decade and then decreases. These changes in hazard rates are further pronounced for major banking centers but not very meaningful according to the LR tests reported in Table 5. Moreover, Figure 6 shows an important specificity of major banking centers that the estimates did not explicitly highlight, which is the fact that the hazard function of major banking centers is spread over a shorter time interval. The slope of the hazard function turns steep when the time elapsed since the last banking crisis is over five decades and the durations between banking crises do not exceed 76 and 102 years for the top eight and five banking centers, respectively, against 181 for other countries.

The longest crisis-free intervals are mainly associated with situations where countries have not yet suffered a banking crisis. Consequently, to take a closer look at the effect of banking center status, we consider the more restrictive selection rule that retains only independent countries that have already faced a banking crisis in the sample to re-estimate Equation (4). The estimates are reported in columns (3) and (4) of Table 5 when the variable Center $_{i, t}$ identifies the top eight and five banking centers, respectively. The results reveal that some previous conclusions are driven by countries that have not yet faced banking crises. ${ }^{23)}$ The coefficients associated with the variable Center $_{i, t}$ and with the interaction terms $\left(\right.$ Basis $_{j, i, t}^{\text {banking }} \times$ Center $\left._{i, t}\right)$ turn insignificant at the $10 \%$ level in columns (3) and (4) of Table 5. Thus, top banking centers

23) The small sample (with and without the more restrictive selection rule) is also used to estimate Equation (4). The results are reported in Appendix 6 and lead to conclusions similar to the ones obtained with Table 5 . 
do not face a higher risk of recidivism of banking crises when the sample of countries that had at least one banking crisis is considered.24) As shown in Figure 6-c, the hazard plot associated with column (3) of Table 5 illustrates the proximity to the time-dependence effect. The only remaining distinction is that the hazard function of major banking centers is spread over a shorter time interval. The durations between banking crises do not exceed 77 years for the top eight banking centers against 107 for other countries.

Figure 6. Hazard plots and the banking center status

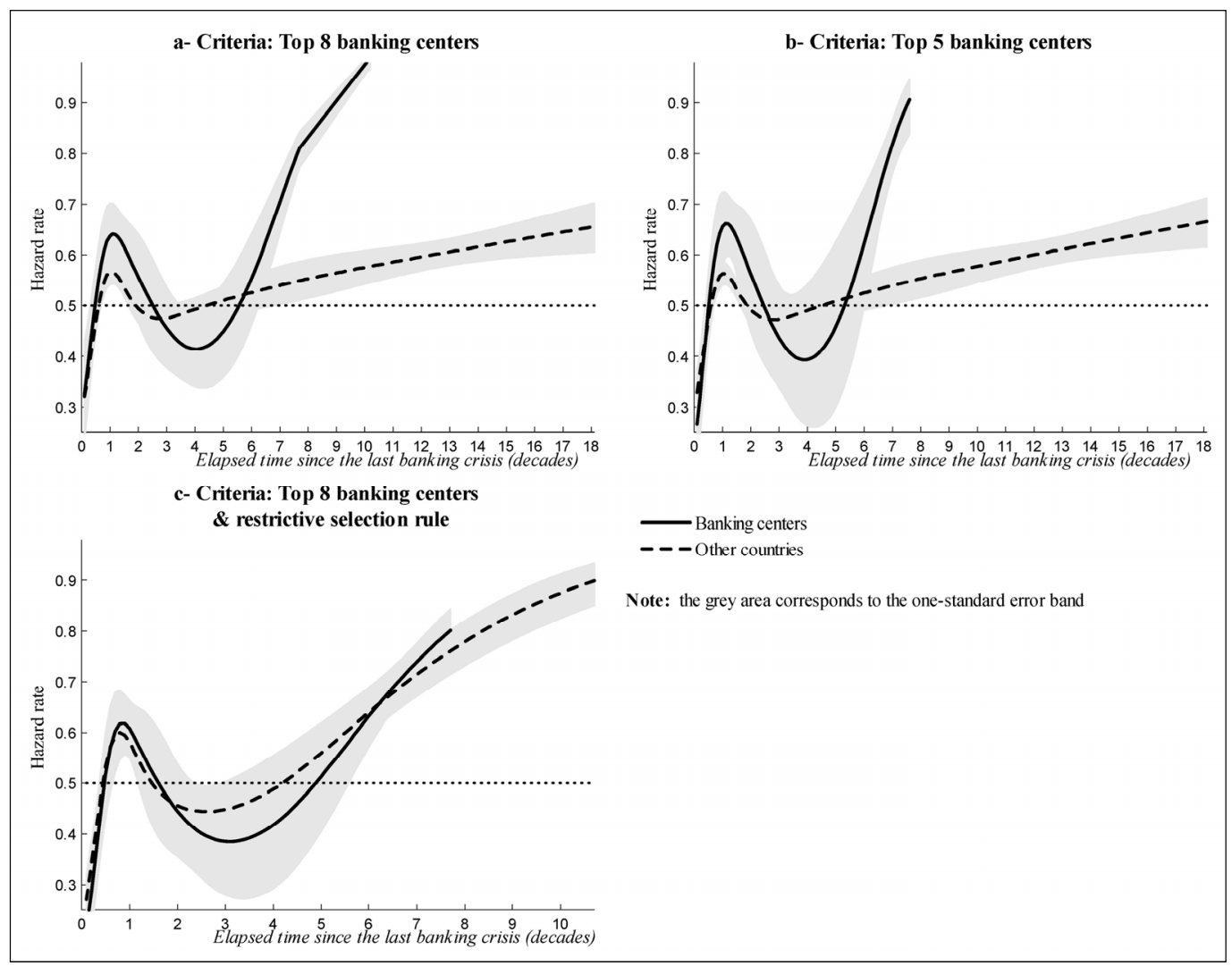

\section{Conclusion}

This paper relies on a discrete-time duration model and on the hazard function identified by that model to investigate the frequency of banking crises. The hazard function provides

24) For a robustness check, we also considered the sub-sample of high-income countries because observations associated with top banking centers mainly belong to high-income countries. The estimates are reported in Appendix 9 and also show that the interaction terms $\left(\right.$ Basis $_{j, i, t}^{\text {banking }} \times$ Center $\left._{i, t}\right)$ are not significant at the $10 \%$ level. 
a quantitative assessment of exposure to banking crises that indicates in particular the ability of countries to graduate from banking crises. First, the duration model serves to confirm that advanced and developing economies face the same exposure to banking crises, that is, the equal opportunity menace of banking crises, documented with descriptive statistics by Reinhart and Rogoff (2008, 2009) and Qian et al. (2011). Second, we extend the model specification to examine whether the hazard function characterizing banking crises depends on criteria other than economic development. Indeed, the economic development level might not be the most obvious criterion that differentiates the degree of exposure to a banking crisis.

Extant literature and financial crisis databases (Reinhart 2010, Laeven \& Valencia 2013) show that banking crises can interact with and appear closely tied to other categories of financial crises. Therefore, we investigated whether the graduation from inflation, currency, and debt crises (assessed by the time elapsed since the last inflation, currency, and debt crisis, respectively) reduces the occurrence of banking crises. According to the results, during inflation or currency crises (or during post inflation or currency crisis periods), countries are prone to banking crises. However, an increased time without inflation, currency, or debt crises does not reduce exposure to banking crises. These results provide a first extension to the equal opportunity menace of banking crises documented by Reinhart and Rogoff $(2008,2009)$ and Qian et al. (2011). The conclusion is that graduation from inflation, currency, or debt crises does not matter in the recurrence of banking crises.

Furthermore, we rely on the status of international banking center to investigate whether core countries in the international financial system are more prone to banking crises. Based on Reed (1981), Choi et al. (1986), Choi et al. (2014), and qualitative works by historians Kindleberger (1974) and Cassis (2010), we obtained a database of major banking centers over the period 1800 2010 that we used to differentiate between countries. The results show that top banking centers have the same exposure to banking crises as countries that had already faced a banking crisis. Therefore, we provide a second extension to the equal opportunity menace of banking crises documented by Reinhart and Rogoff $(2008,2009)$ and Qian et al. (2011): central and peripheral countries in the international financial system face similar recurrences of banking crises.

Thus, relying on a duration model, this paper brings new insights into the prevalence of banking crises from a long-term perspective. Additional contributions to the literature on the quantitative history of financial crises can be investigated through such an approach. For instance, in this paper we only focused on the risk of banking crises. A natural extension of this work might be to also consider exposure to inflation, currency, and debt crises to compare the recurrence of these different categories of crises. It might also be worth assessing the hazard functions of non-banking financial crises. Comparing the shape of the hazard functions of the different types of financial crises would highlight the graduation from each type of financial crisis. A lower recurrence (i.e., a flatter hazard function) of default and inflation crises might be expected 
if some countries graduated from these types of crises (Reinhart \& Rogoff 2008, 2009, Qian et al. 2011). Further, regarding methodological aspects, multivariate models might be the appropriate approach to properly account for potential interactions between the different types of financial crises. Multivariate logit models have been applied to financial crises (Falcetti \& Tudela 2008, Reinhart \& Rogoff 2011) and might be extended to capture the time dependence (i.e., the hazard function).

\section{References}

Balderston, T. (1991). "German banking between the wars: The crisis of the credit banks." Business History Review, 65, no. 3, 554-605.

Bank for International Settlements. (2011). The impact of sovereign credit risk on bank funding conditions. Technical Report 43.

Beck, N., Katz, J., and Tucker, R. (1998). "Taking time seriously: Time-series-cross-section analysis with a binary dependent variable." American Journal of Political Science, 42, no. 4, 1260-1288.

Bordo, M., Eichengreen, B., Klingebiel, D., and Martinez-Peria, M. S. (2001). "Is the crisis problem growing more severe?" Economic Policy, 16, no. 32, 51-82.

Bouvatier, V. (2017). "The frequency of banking crises in a dynamic setting: A discrete-time duration approach." Oxford Economic Papers, 69, no. 4, 1078-1100.

Braudel, F. (1982). Civilization and Capitalism, 15th-18th Century: The Structures of Everyday Life (vol 1.), The wheels of commerce (vol.2), The Perspective of the World (vol. 3). University of California Press.

Calomiris, C. W., and Haber, S. H. (2014). Fragile by design: the political origins of banking crises and scarce credit. The Princeton economic history of the Western world. Princeton University Press.

Cassis, Y. (2010). Capitals of Capital: The Rise and Fall of International Financial Centres 1780-2009. Cambridge University Press; 2 edition.

Cecchetti, S. G., and Kharroubi, E. (2015). Why does financial sector growth crowd out real economic growth? BIS Working Papers 490, Bank for International Settlements.

Chaudron, R., and de Haan, J. (2014). "Dating banking crises using incidence and size of bank failures: Four crises reconsidered." Journal of Financial Stability, 15, 63-75.

Choi, S.-R., Park, D., and Tschoegl, A. (2014). Banks and the world's major financial centers, 2010. Working Paper 14-16, Wharton Financial Institutions Center.

Choi, S.-R., Tschoegl, A., and Yu, C.-M. (1986). "Banks and the world's major financial centers, 1970-1980." Review of World Economics, 122, no. 1, 48-64.

Corbridge, S., Thrift, N., and Martin, R. (1994). Money, power, and space. Blackwell Publishers.

Cottrell, P. L. (2007). Centres and peripheries in banking: the historical development of financial markets. Ashgate Publishing, Ltd.

DeLong, E. R., DeLong, D. M., and Clarke-Pearson, D. L. (1988). "Comparing the areas under two 
or more correlated receiver operating characteristic curves: A nonparametric approach.” Biometrics, $44,837-845$.

Demirgüç-Kunt, A., and Detragiache, E. (1998). "The determinants of banking crises in developing and developed countries." IMF Staff Papers, 45, no. 1, 81-109.

Drehmann, M., and Juselius, M. (2014). "Evaluating early warning indicators of banking crises: Satis-fying policy requirements." International Journal of Forecasting, 30, no. 3, 759-780.

Égert, B. (2015). "The 90\% public debt threshold: the rise and fall of a stylized fact." Applied Economics, 47 , no. 34-35, 3756-3770.

Eichengreen, B., and Arteta, C. (2000). Banking Crises in Emerging Markets: Presumptions and Evidence. Center for International and Development Economics Research (CIDER) Working Papers C00-115, University of California at Berkeley.

Eichengreen, B. J., and Flandreau, M. (1997). The gold standard in theory and history. Psychology Press.

Falcetti, E. \& Tudela, M. (2008). "What do twins share? A joint probit estimation of banking and currency crises." Economica, 75, no. 298, 199-221.

Friedman, M., and Schwartz, A. (1963). A Monetary History of the United States, 1867-1960. Princeton University Press.

Glick, R., and Hutchison, M. (1999). Banking and currency crises: how common are twins? Pacific Basin Working Paper Series 99-07, Federal Reserve Bank of San Francisco.

Harrell, F. (2001). Regression Modeling Strategies: With Applications to Linear Models, Logistic Regression, and Survival Analysis. Springer.

Herndon, T., Ash, M., and Pollin, R. (2014). "Does high public debt consistently stifle economic growth? a critique of reinhart and rogoff." Cambridge journal of economics, 38, no. 2, 257-279.

Heston, A., Summers, R., and Aten, B. (2012). Penn World Table Version 7.1. Center for international comparisons of production, income and prices, University of Pennsylvania.

Kaminsky, G. L., and Reinhart, C. M. (1999). "The twin crises: The causes of banking and balance-of-payments problems." American Economic Review, 89, no. 3, 473-500.

Kindleberger, C. (1974). The Formation of Financial Centers: A study in Comparative Economic History. Princeton Studies in International Finance 36, Princeton University.

Laeven, L., and Valencia, F. (2013). "Systemic banking crises database." IMF Economic Review, 61, no. $2,225-270$.

Levine, R. (2005). "Finance and growth: theory and evidence." Handbook of economic growth, 1, 865-934.

Maddison, A. (2009). Historical Statistics for the World Economy: 1-2008 AD. Technical report, http://ww w.ggdc.net/maddison/oriindex.htm (accessed December 2012).

Minsky, H. (1986). Stabilizing an unstable economy. A Twentieth Century Fund report. Yale University Press.

Mishkin, F. S. (1996). Understanding Financial Crises: A Developing Country Perspective. Working Paper 5600, National Bureau of Economic Research.

Obstfeld, M., and Taylor, A. (2004). Global capital markets: Integration, crisis, and growth. Japan-US Center UFJ Bank Monographs on International Financial Markets. Cambridge University Press.

Parent, A. (2012). "A critical note on This time is different." Cliometrica, 6, no. 2, 211-219. 
Qian, R., Reinhart, C. M., and Rogoff, K. S. (2011). "On graduation from default, in ₹ation and banking crises: Elusive or illusion?” In NBER Macroeconomics Annual 2010, Volume 25 (pp. 1-36). National Bureau of Economic Research, Inc.

Reed, H. C. (1981). The Preeminence of International Financial Centers. Praeger.

Reinhart, C. M. (2010). This Time is different chartbook: Country histories on debt, default, and financial crises. Working Paper 15815, National Bureau of Economic Research.

Reinhart, C. M., and Rogoff, K. S. (2008). Banking crises: An equal opportunity menace. Working Paper 14587, National Bureau of Economic Research.

Reinhart, C. M., and Rogoff, K. S. (2009). This time is different: Eight centuries of financial folly. Princeton: Princeton University Press.

Reinhart, C. M., and Rogoff, K. S. (2011). "from financial crash to debt crisis." American Economic Review, 101, no. 5, 1676-1706.

Royston, P., and Parmar, M. K. B. (2002). "Flexible parametric proportional-hazards and proportional-odds models for censored survival data, with application to prognostic modelling and estimation of treatment effects." Statistics in Medicine, 21, no. 15, 2175-2197.

Royston, P., and Sauerbrei, W. (2007). "Multivariable modeling with cubic regression splines: A princi-pled approach." Stata Journal, 7, no. 1, 45-70.

Sassen, S. (1991). The global city: New York, London, Tokyo. Princeton University Press.

Sassen, S. (1999). "Global financial centers.” Foreign Affairs, 78, no. 1, 75-87.

Schularick, M., and Taylor, A. M. (2012). "Credit booms gone bust: Monetary policy, leverage cycles, and financial crises, 1870-2008." American Economic Review, 102, no. 2, 1029-61.

Stoker, J. H. (1995). Intermediation and the business cycle under a specie standard: the role of the gold standard in English financial crises: 1790-1850. University of Chicago, Chicago.

Triffin, R. (1964). The evolution of the international monetary system: Historical reappraisal and future perspectives. International Finance Section, Department of Economics, Princeton University. 


\section{Appendix 1: Descriptive statistics and data sources}

Data sources:

- $Y$ : crisis dummy, from Reinhart (2010) and Laeven \& Valencia (2013).

- KMobility: judgmental capital mobility index, from Obstfeld \& Taylor (2004).

$-G D P_{i, t}^{\text {PerCapita }}$ : GDP per capita, from the Total Economy Database provided by the Groningen Growth and Development Centre, the historical database developed by Maddison (2009) and the Penn World Table (Heston et al. (2012)).

-Inflation: inflation rate, from Reinhart \& Rogoff (2009) and from the World Development Indi-cators (WDI) database provided by the World Bank.

Table A1. Descriptive statistics

\begin{tabular}{|c|c|c|c|c|c|c|}
\hline & Obs. & Mean & Median & Std.Dev. & Min & Max \\
\hline$Y($ banking crisis dummy) & 10047 & 0.0334 & 0 & 0.1797 & 0 & 1 \\
\hline Share crisis $^{\text {in } \%)}$ & 10047 & 5.7827 & 3.0075 & 6.3199 & 0 & 42 \\
\hline KMobility & 10047 & 0.4628 & 0.3625 & 0.2997 & 0.0500 & 0.9250 \\
\hline Count & 10047 & 1.9022 & 1 & 2.6596 & 0 & 14 \\
\hline Period $^{1800 ~ ~ 1820}$ & 10047 & 0.0251 & 0 & 0.1566 & 0 & 1 \\
\hline Period $^{1821 ~ ~ 1913}$ & 10047 & 0.2199 & 0 & 0.4142 & 0 & 1 \\
\hline Period $^{1914 ~ ~ 1946}$ & 10047 & 0.1126 & 0 & 0.3162 & 0 & 1 \\
\hline Period $^{1946 ~ ~ 1972}$ & 10047 & 0.1659 & 0 & 0.3720 & 0 & 1 \\
\hline$G D P^{P e r C a p}$ & 10047 & 0.2061 & -0.1663 & 1.0266 & -1.1310 & 5.0782 \\
\hline Income $e^{\text {High }}$ & 10672 & 0.4034 & 0 & 0.4906 & 0 & 1 \\
\hline Income $e^{\text {Low }}$ & 10672 & 0.1145 & 0 & 0.3184 & 0 & 1 \\
\hline In flation & 10047 & 9.9398 & 4.5928 & 29.7762 & -112.7012 & 547.7910 \\
\hline$D^{H \operatorname{lgh}(75 t h}$ percentile of $\left.G D P^{\text {PerCap }}\right)$ & 10047 & 0.3108 & 0 & 0.4628 & 0 & 1 \\
\hline Center (Top 8) & 10047 & 0.1009 & 0 & 0.3012 & 0 & 1 \\
\hline Center (Top 5$)$ & 10047 & 0.0755 & 0 & 0.2642 & 0 & 1 \\
\hline
\end{tabular}

Table A2. Variance Inflation Factors (VIF)

\begin{tabular}{ll}
\hline Share $^{\text {crisis }}$ & 1.48 \\
KMobility & 2.05 \\
Count & 1.62 \\
Period $^{1800 ~ 1820}$ & 1.22 \\
Period $^{1821 ~ 1913}$ & 1.58 \\
Period $^{1914 \sim 1946}$ & 1.52 \\
Period $^{1946 \sim 1972}$ & 2.13 \\
GDP $^{\text {PerCap }}$ & 1.53 \\
Inflation $_{\text {Center }}$ & 1.07 \\
\hline
\end{tabular}




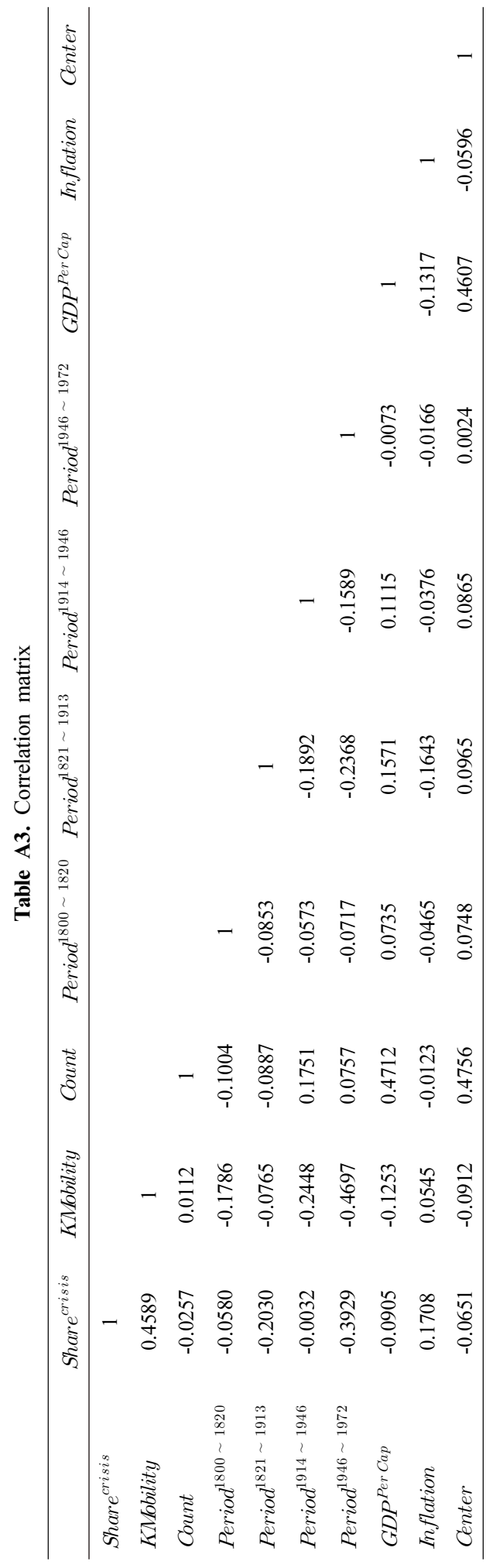




\section{Appendix 2: Modeling time dependence}

The baseline model is written as follows:

$$
P\left(Y_{i, t}=1\right)=\frac{1}{1+\exp \left[-X_{i, t} \beta-\sum_{j=0}^{n} b_{j} \text { Basis }_{j, i, t}\right]}
$$

where the subscripts refer to country $i$ in period $t$. The variable $Y_{i, t}$ is a binary variable that is equal to 1 if a crisis occurs and 0 otherwise, $X_{i, t}$ is a set of control variables and the variables $\operatorname{Basis}_{j}(j=0, \cdots, n)$ are the variables used to capture the time dependence.

The variables Basis $_{j}$ are the basis variables obtained from a restricted cubic spline function. A spline function is defined as a smooth polynomial function that is piecewise-defined. More precisely, the spline function depends on the variable $\mathrm{d}$ marking the duration of the sequence of zeros since the last crisis (with $d=1,2, \cdots, D$ ). The places where the polynomial pieces connect are referred to as knots and are used to introduce changes in the relationship between the endogenous variable and the duration $d$.

Considering $n+2$ knots at $k_{\text {min }}<k_{1}<\cdots<k_{n}<k_{\max }$, an unrestricted cubic spline function is written as follows (Royston \& Sauerbrei 2007):25)

$$
\left.S(d)=\beta_{00}+\beta_{10} d+\beta_{20} d^{2}+\beta_{30} d^{3}+\sum_{j=1}^{n} \beta_{j}\left(d-k_{j}\right)_{+}^{3}+\beta_{k_{\min }}\left(d-k_{\min }\right)_{+}^{3}+\beta_{\left(k_{\min }\right.}\right)\left(d-k_{\max }\right)_{+}^{3}
$$

where the plus function $(d-k)_{+}$is defined as:

$$
(d-k)_{+}=\left\{\begin{array}{l}
d-k \text { if } d \geq k \\
0 \quad \text { otherwise }
\end{array}\right.
$$

The terminology "restricted cubic spline" (or natural cubic spline) refers to the constraints imposed on $S(d)$, which imply linearity beyond the boundary knots $\left(k_{\min }\right.$ and $\left.\left.k_{\max }\right) .26\right)$ This requirement tends to avoid wild behavior near the extreme values of the data. Then, the restricted cubic spline function is written as (Royston \& Parmar (2002) (p.2194) for the algebraic details):

$$
S(d)=\gamma_{0}+\gamma_{1} \text { Basis }_{0}+\gamma_{2} \text { Basis }_{1}+\cdots+\gamma_{n+1} \text { Basis }_{n}
$$

25) $k_{\min }$ and $k_{\max }$ are the boundary knots and will not be placed at the extremes of $d$; as suggested by Harrell (2001).

26) For example, the linearity constraint below $k_{\min }$ (i.e., when $d<k_{\max }$ ) requires that quadratic and cubic terms must vanish, and hence, $\beta_{20}=\beta_{30}=0$ 
with $\gamma_{0}=\beta_{00}, \gamma_{1}=\beta_{10}, \gamma_{j+1}=\beta_{j}$ for $j=1, \cdots, n$ and

$$
\begin{aligned}
& \text { Basis }_{0}=d \\
& \text { Basis }_{j}=\left(d-k_{j}\right)_{+}^{3}-\lambda_{j}\left(d-k_{\text {min }}\right)_{+}^{3}-\left(1-\lambda_{j}\right)\left(d-k_{\text {max }}\right)_{+}^{3} \text { for } j=1, \cdots, n
\end{aligned}
$$

with $\lambda_{j}=\frac{k_{\max }-k_{j}}{k_{\max }-k_{\min }}$.

Next, the basis variables $\left(\right.$ Basis $_{0}, \cdots$, Basis $_{n}$ ) can be added to the regressors in the logit specification to capture the time dependence. However, the basis variables have been orthogonalized before being included in the logit specification, as suggested by Royston \& Sauerbrei (2007). Without any transformation, the basis variables are highly correlated.

The main issue related to restricted cubic splines concerns the choice of the number of knots and their locations. Harrell (2001) recommends placing knots at equally spaced percentiles of the duration variable. In applied use, the number of knots generally varies between three and seven. We use five knots (from which four basis variables are obtained), as suggested by Harrell (2001) for a large sample, and various numbers of knots have also been used for a robustness check. When five knots are considered, the default percentiles provided by Harrell (2001) are $5 \%, 27.5 \%, 50 \%, 72.5 \%$ and $95 \%$. The lower and higher knots are then placed near the extreme values, and the remaining knots are placed so that the proportion of observations between the knots is constant.

The specification of the duration variable $(d)$ requires two clarifications concerning the treatment of the data. First, the crises reported in the Reinhart (2010) database can take place over the course of several years. Beck et al. (1998) recommend dropping all but the first year of these multi-year events so that yearly observations can be considered as independent of each other. Second, the dataset is left-censored: the sample starts in 1800 and there is no information concerning the duration between the first crisis recorded in the database for a given country and the previous crisis dating back before 1800 in this country. In addition, the sample is unbalanced because only independent countries are considered in 1800. Therefore, some countries entered the dataset only after they became independent. Following Beck et al. (1998), the variable $d_{i, t}$ is set to 1 when country $i$ enters the dataset, i.e., in 1800 or when it became independent. 


\section{Appendix 3: Time dependence in banking crises: robustness checks for the baseline specification}

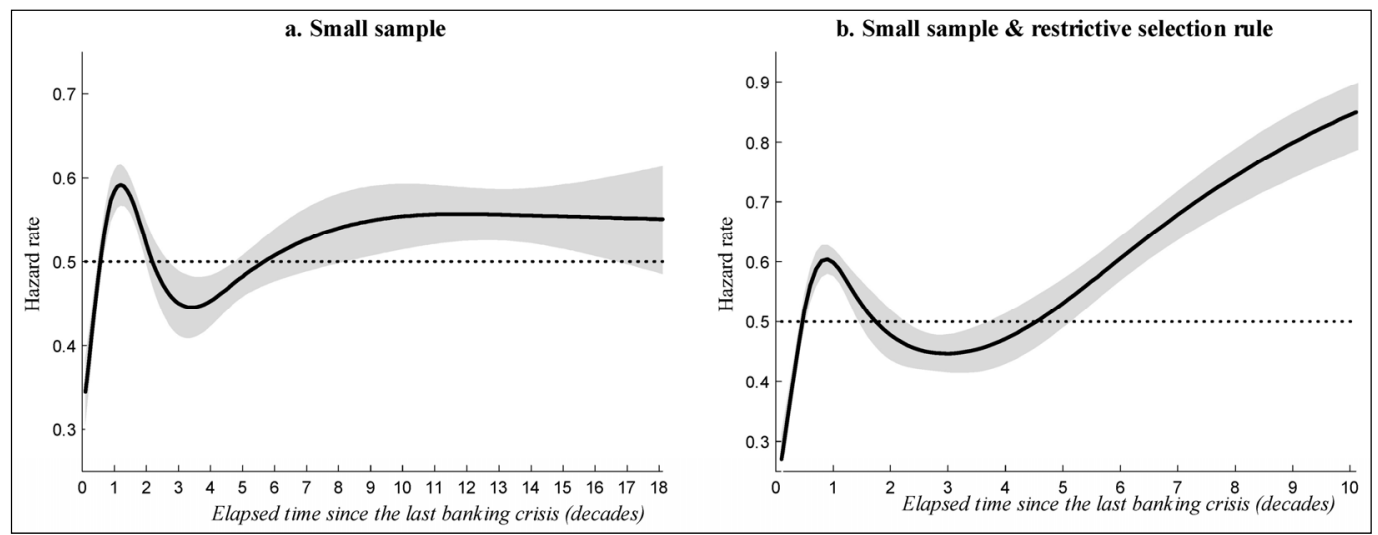

(Note) the grey area corresponds to the one-standard error band

\section{Appendix 4: The influence of non-baking financial crises: small sample \& restrictive selection rule}

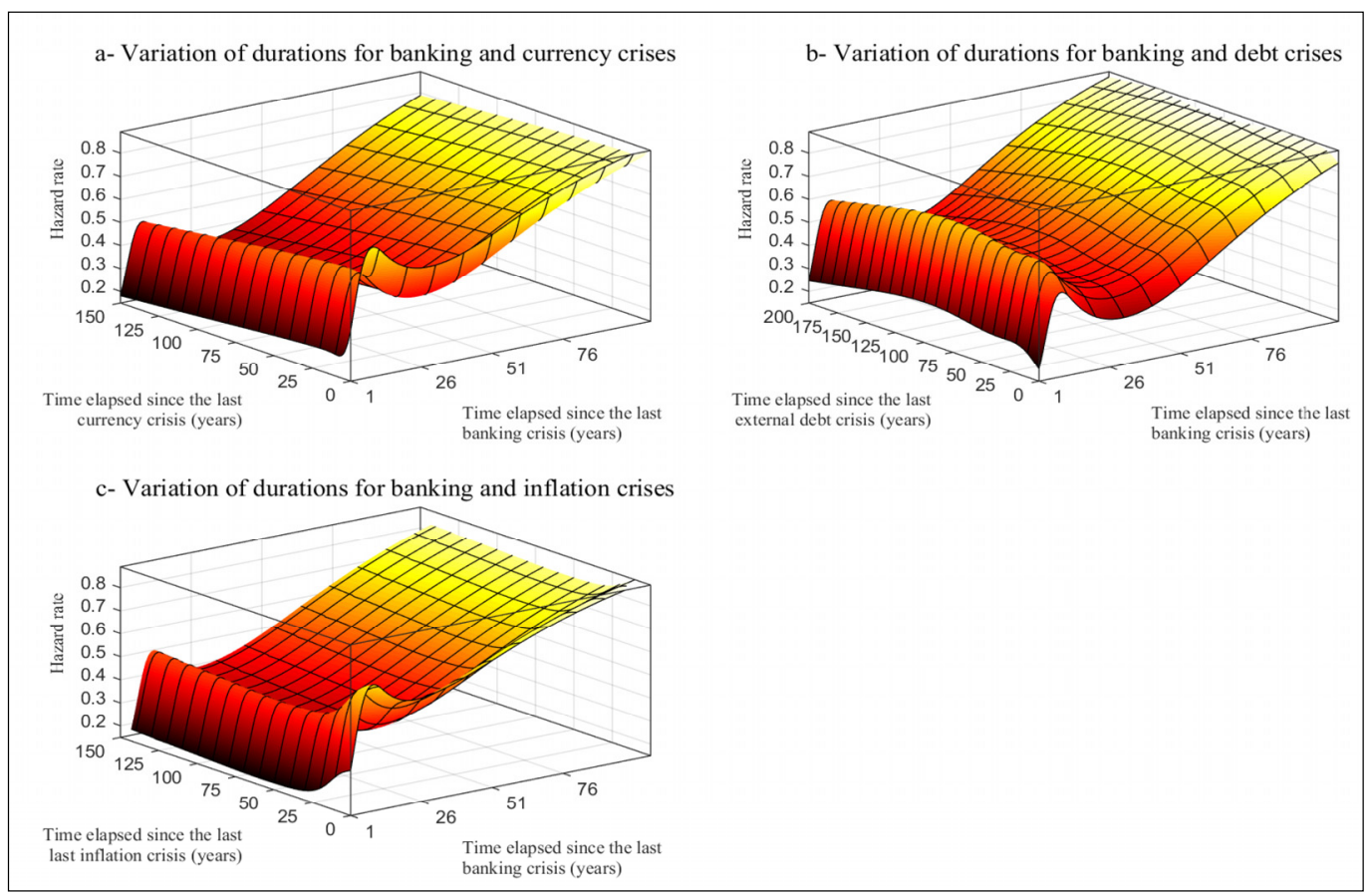




\section{Appendix 5: Time dependence and advanced economies (robustness checks)}

\begin{tabular}{|c|c|c|c|c|c|c|c|c|}
\hline Sample: & \multicolumn{2}{|c|}{$\begin{array}{c}(1) \\
\text { Small }\end{array}$} & $\begin{array}{r}(2 \\
\text { Baseline \& } \\
\text { selectio }\end{array}$ & $\begin{array}{l}\text { restrictive } \\
\text { rule }\end{array}$ & \multicolumn{2}{|c|}{$\begin{array}{c}\text { (3) } \\
\text { Samll \& restrictive } \\
\text { selection rule }\end{array}$} & \multicolumn{2}{|c|}{$\begin{array}{l}\text { (4) } \\
\text { Samll \& restrictive } \\
\text { selection rule }\end{array}$} \\
\hline \multirow[t]{2}{*}{$\begin{array}{l}\text { Criteria to define } \\
\text { the variable } D_{i, t}^{\text {High }}\end{array}$} & \multicolumn{2}{|c|}{$\begin{array}{l}\text { high-income group } \\
\quad\left(\text { Income }_{i}^{\text {High }}\right)\end{array}$} & \multicolumn{2}{|c|}{$\begin{array}{l}\text { high-income group } \\
\quad\left(\text { Income }_{i}^{\text {High }}\right)\end{array}$} & \multicolumn{2}{|c|}{$\begin{array}{c}\text { 75th percentile of } \\
\qquad G D P_{i, t-1}^{P e r C a p}\end{array}$} & \multicolumn{2}{|c|}{$\begin{array}{l}\text { high-income group } \\
\quad\left(\text { Income }_{i}^{\text {High }}\right)\end{array}$} \\
\hline & Coef. & S.E. & Coef. & S.E. & Coef. & S.E. & Coef. & S.E. \\
\hline Share $_{t-1}^{\text {crisis }}$ & $0.0212 * * *$ & $(0.0065)$ & $0.0191^{* *}$ & $(0.0083)$ & $0.0180 * *$ & $(0.0072)$ & $0.0184 * * *$ & $(0.0071)$ \\
\hline KMobility & $1.0223 * * *$ & $(0.3578)$ & $0.7548 *$ & $(0.4224)$ & $1.1277 * * *$ & $(0.3700)$ & $1.0390 * * *$ & $(0.4020)$ \\
\hline Count $_{i, t-1}$ & 0.0283 & $(0.0225)$ & $0.0712 * * *$ & $(0.0216)$ & 0.0245 & $(0.0221)$ & 0.0245 & $(0.0209)$ \\
\hline Period $_{t}^{1800 ~ ~ 1820}$ & 0.3355 & $(0.4115)$ & $1.4136^{* * *}$ & $(0.3434)$ & $1.0943 * * *$ & $(0.3473)$ & $1.2495 * * *$ & $(0.3621)$ \\
\hline $\operatorname{Period}_{t}^{1821 \sim 1913}$ & 0.1695 & $(0.2044)$ & $0.8344 * * *$ & $(0.2320)$ & $0.7172 * * *$ & $(0.2487)$ & $0.6793 * * *$ & $(0.2463)$ \\
\hline $\operatorname{Period}_{t}^{1914 \sim 1945}$ & $0.7096^{* *}$ & $(0.2855)$ & $1.1827 * * *$ & $(0.3372)$ & $1.2600^{* * *}$ & $(0.3206)$ & $1.1592 * * *$ & $(0.3304)$ \\
\hline Period $_{t}^{1946 ~ ~} 1972$ & $-2.4570 * * *$ & $(0.6315)$ & $-2.1133 * * *$ & $(0.7205)$ & $-2.0248 * * *$ & $(0.7525)$ & $-2.1397 * * *$ & $(0.7332)$ \\
\hline$G D P_{i, t-1}^{\text {Per Cap }}$ & 0.0297 & $(0.0886)$ & 0.0726 & $(0.0869)$ & 0.0649 & (0.1237) & -0.0017 & (0.0909) \\
\hline In $_{\text {flation }}, t-1$ & $0.0068 * * *$ & $(0.0011)$ & $0.0056^{* * *}$ & $(0.0015)$ & $0.0069 * * *$ & $(0.0018)$ & $0.0070^{* * *}$ & $(0.0018)$ \\
\hline$D_{i, t}^{\text {High }}$ & 0.0743 & $(0.1936)$ & -0.1034 & $(0.2322)$ & -0.2197 & $(0.2530)$ & -0.0617 & $(0.2242)$ \\
\hline Intercept & $-4.1609 * * *$ & $(0.2672)$ & $-4.4977 * * *$ & $(0.3797)$ & $-4.3934 * * *$ & $(0.3316)$ & $-4.3170 * * *$ & $(0.3629)$ \\
\hline Basis $_{0, i, t}^{\text {banking }}$ & 0.0562 & $(0.0759)$ & 0.2262 & $(0.1615)$ & 0.1033 & $(0.1353)$ & 0.2033 & $(0.1708)$ \\
\hline Basis $_{1, i, t}^{\text {banking }}$ & 0.0124 & $(0.1009)$ & -0.0920 & $(0.0962)$ & -0.0816 & $(0.0858)$ & -0.0300 & $(0.0998)$ \\
\hline Basis $_{2, i, t}^{\text {banking }}$ & $-0.1769 * *$ & $(0.0851)$ & $-0.3180 * * *$ & $(0.1074)$ & $-0.3308 * * *$ & $(0.0887)$ & $-0.3123 * * *$ & $(0.1083)$ \\
\hline Basis $_{3, i, t}^{\text {banking }}$ & 0.0200 & $(0.1150)$ & $0.2209 *$ & $(0.1223)$ & 0.0616 & $(0.1110)$ & 0.1458 & $(0.1260)$ \\
\hline Basis $_{0, i, t}^{\text {banking }} \times D_{i, t}^{\text {High }}$ & 0.1063 & $(0.2474)$ & 0.0543 & $(0.1708)$ & 0.2253 & $(0.1730)$ & 0.0315 & $(0.1807)$ \\
\hline Basis $_{1, i, t}^{\text {banking }} \times D_{i, t}^{\text {High }}$ & -0.0599 & $(0.1992)$ & 0.0412 & $(0.1379)$ & 0.0790 & $(0.1609)$ & -0.0734 & $(0.1388)$ \\
\hline Basis $_{2, i, t}^{\text {banking }} \times D_{i, t}^{\text {High }}$ & -0.0374 & $(0.1326)$ & -0.1714 & $(0.1333)$ & -0.1721 & $(0.1590)$ & -0.1662 & $(0.1368)$ \\
\hline Basis $_{3, i, t}^{\text {banking }} \times D_{i, t}^{\text {High }}$ & $0.2478^{*}$ & $(0.1493)$ & $-0.3589 * *$ & $(0.1628)$ & -0.1306 & $(0.1705)$ & -0.2669 & $(0.1655)$ \\
\hline Log-likelihood & -1083.96 & & -866.15 & & -787.63 & & -787.95 & \\
\hline Pseudo $R^{2}$ & 0.0784 & & 0.0769 & & 0.0781 & & 0.0778 & \\
\hline AUROC curve & 0.7225 & & 0.7234 & & 0.7061 & & 0.7067 & \\
\hline $\begin{array}{l}\text { AUROC test } \\
{[p \text {-value }]}\end{array}$ & $\begin{array}{c}1.94 \\
{[0.1637]}\end{array}$ & & $\begin{array}{c}0.83 \\
{[0.3636]}\end{array}$ & & $\begin{array}{c}0.51 \\
{[0.4766]}\end{array}$ & & $\begin{array}{c}0.93 \\
{[0.3355]}\end{array}$ & \\
\hline $\begin{array}{l}\text { LR test } \\
\qquad[p \text {-value }]\end{array}$ & $\begin{array}{c}4.47 \\
{[0.4833]}\end{array}$ & & $\begin{array}{c}8.29 \\
{[0.1407]}\end{array}$ & & $\begin{array}{c}8.29 \\
{[0.1407]}\end{array}$ & & $\begin{array}{c}4.61 \\
{[0.4655]}\end{array}$ & \\
\hline No. obs. & 7424 & & 5786 & & 4689 & & 4689 & \\
\hline No. countries & 70 & & 123 & & 68 & & 68 & \\
\hline No. crises & 275 & & 221 & & 209 & & 209 & \\
\hline
\end{tabular}

(Note) $* * *, * *$ and $*$ indicate signi $\cdots$ cance respectively at the $1 \%, 5 \%$ and $10 \%$ levels. Cluster robust standard deviations are in brackets. The null hypothesis of the LR test is that the likelihoods are equal in the specifications with and without the 4 interaction variables. The null hypothesis of the AUROC test is that the AUROC curves are equal in the specifications with and without the 4 interaction variables. 


\section{Appendix 6: Effects of cumency and extemal debt crises on banking crises: robustness check with baseline sample and the restrictive selection rule}

\begin{tabular}{|c|c|c|c|c|c|c|}
\hline \multirow{3}{*}{ Non-banking Crisis $(K)$ : } & \multicolumn{2}{|c|}{$\begin{array}{l}\text { (1) } \\
\text { Baseline \& restrictive } \\
\text { selection rule }\end{array}$} & \multicolumn{2}{|c|}{$\begin{array}{c}\text { Baseline \& restrictive } \\
\text { selection rule }\end{array}$} & \multicolumn{2}{|c|}{$\begin{array}{c}\text { Baseline \& restrictive } \\
\text { selection rule }\end{array}$} \\
\hline & \multicolumn{2}{|c|}{$K=$ currency } & \multicolumn{2}{|c|}{$K=d e b t$} & \multicolumn{2}{|c|}{$K=$ currency, debt } \\
\hline & Coef. & S.E. & Coef. & S.E. & Coef. & S.E. \\
\hline Share $_{t-1}^{\text {crisis }}$ & $0.0159 *$ & $(0.0083)$ & $0.0198 * *$ & $(0.0086)$ & $0.0161 *$ & $(0.0083)$ \\
\hline KMobility $_{t}$ & $1.0353 * *$ & $(0.4034)$ & $0.7331 *$ & $(0.3879)$ & $0.9329 * *$ & $(0.4070)$ \\
\hline Count $_{i, t-1}$ & $0.0547 * * *$ & $(0.0212)$ & $0.0604 * *$ & $(0.0247)$ & 0.0395 & $(0.0263)$ \\
\hline $\operatorname{Period}_{t}^{1800 \sim 1820}$ & $1.3289 * * *$ & $(0.3775)$ & $1.3981^{* * *}$ & $(0.4003)$ & $1.4232 * * *$ & $(0.3995)$ \\
\hline $\operatorname{Period}_{t}^{1821 \sim 1913}$ & $0.9970 * * *$ & $(0.2110)$ & $0.7237 * * *$ & $(0.2216)$ & $0.9342 * * *$ & $(0.1997)$ \\
\hline $\operatorname{Period}_{t}^{1914 \sim 1945}$ & $1.2444 * * *$ & $(0.3286)$ & $1.0855^{* * *}$ & $(0.3206)$ & $1.1467 * * *$ & $(0.3255)$ \\
\hline $\operatorname{Period}_{t}^{1946 \sim 1972}$ & $-2.0833^{* * *}$ & $(0.7382)$ & $-2.2101 * * *$ & $(0.7212)$ & $-2.1597 * * *$ & $(0.7371)$ \\
\hline$G D P_{i, t-1}^{P e r C a p}$ & 0.1079 & $(0.0733)$ & 0.0137 & $(0.0778)$ & 0.0331 & $(0.0786)$ \\
\hline Inflation $_{i, t-1}$ & $0.0042 * *$ & $(0.0019)$ & $0.0058^{* * *}$ & $(0.0015)$ & $0.0045^{* *}$ & $(0.0018)$ \\
\hline Intercept & $-4.7063 * * *$ & $(0.3598)$ & $-4.4369 * * *$ & $(0.3382)$ & $-4.5375^{* * *}$ & $(0.3585)$ \\
\hline Basis $_{0, i, t}^{\text {banking }}$ & $0.2290 * * *$ & $(0.0754)$ & $0.2297 * * *$ & $(0.0698)$ & $0.2326^{* * *}$ & $(0.0713)$ \\
\hline Basis $_{1, i, t}^{\text {banking }}$ & 0.0123 & $(0.0750)$ & -0.0128 & $(0.0739)$ & 0.0206 & $(0.0771)$ \\
\hline Basis $_{2, i, t}^{\text {banking }}$ & $-0.3836^{* * *}$ & $(0.0594)$ & $-0.3906 * * *$ & $(0.0637)$ & $-0.3804 * * *$ & $(0.0602)$ \\
\hline Basis $_{3, i, t}^{\text {banking }}$ & 0.0503 & $(0.0764)$ & 0.0420 & $(0.0753)$ & 0.0500 & $(0.0762)$ \\
\hline Basis currency $_{0, i}$ & $-0.1419 * *$ & $(0.0656)$ & & & $-0.1855 * * *$ & $(0.0633)$ \\
\hline Basis ${ }_{1, i, t}^{\text {currency }}$ & $-0.1620^{* *}$ & $(0.0727)$ & & & $-0.1483 * *$ & $(0.0730)$ \\
\hline Basis $_{2, i, t}^{\text {currency }}$ & $0.1659^{*}$ & $(0.0912)$ & & & $0.1662 *$ & $(0.0965)$ \\
\hline Basis $_{3, i, t}^{\text {currency }}$ & -0.0167 & $(0.0810)$ & & & -0.0204 & $(0.0807)$ \\
\hline Basis $_{0, i, t}^{\text {debt }}$ & & & 0.0946 & $(0.0856)$ & $0.1521^{*}$ & $(0.0857)$ \\
\hline Basis $_{1, i, t}^{\text {debt }}$ & & & 0.0588 & $(0.0644)$ & 0.0934 & $(0.0664)$ \\
\hline Basis $_{2, i, t}^{\text {debt }}$ & & & 0.0838 & $(0.0850)$ & 0.0638 & $(0.0913)$ \\
\hline Basis $_{3, i, t}^{\text {debt }}$ & & & 0.0466 & $(0.0823)$ & 0.0300 & $(0.0823)$ \\
\hline Log-likelihood & -863.3813 & & -868.6001 & & -861.0286 & \\
\hline Pseudo $R^{2}$ & 0.0798 & & 0.0743 & & 0.0823 & \\
\hline AUROC curve & 0.7345 & & 0.7210 & & 0.7242 & \\
\hline $\begin{array}{l}\text { AUROC test } \\
{[p \text {-value }]}\end{array}$ & $\begin{array}{c}4.88 \\
{[0.0271]}\end{array}$ & & $\begin{array}{c}0.35 \\
{[0.5556]}\end{array}$ & & $\begin{array}{c}5.90 \\
{[0.0151]}\end{array}$ & \\
\hline $\begin{array}{l}\text { LR test } \\
\qquad[p \text {-value }]\end{array}$ & $\begin{array}{c}13.84 \\
{[0.0078]}\end{array}$ & & $\begin{array}{c}3.40 \\
{[0.4927]}\end{array}$ & & $\begin{array}{c}18.55 \\
{[0.0175]}\end{array}$ & \\
\hline No. obs. & 5786 & & 5786 & & 5786 & \\
\hline No. countries & 123 & & 123 & & 123 & \\
\hline No. crises & 221 & & 221 & & 221 & \\
\hline
\end{tabular}

(Note) $* * *, * *$ and $*$ indicate significance respectively at the $1 \%, 5 \%$ and $10 \%$ levels. Cluster robust standard deviations are in brackets. The null hypothesis of the LR test is that the likelihoods are equal in the specifications with and without the basis variables associated with non-banking financial crises. The null hypothesis of the AUROC test is that the AUROC curves are equal in the specifications with and without the basis variables associated with non-banking financial crises. 


\section{Appendix 7: Effects of currency and extemal debt crises on banking crises: robustness check with the small sample and the restrictive selection rule}

\begin{tabular}{|c|c|c|c|c|c|c|c|c|}
\hline \multirow{3}{*}{$\begin{array}{c}\text { Sample: } \\
\text { Non-banking crisis: }\end{array}$} & \multicolumn{2}{|c|}{$\begin{array}{l}(1) \\
\text { Small \& restrictive }\end{array}$} & \multicolumn{2}{|c|}{$\begin{array}{c}(2) \\
\text { Small \& restrictive }\end{array}$} & \multicolumn{2}{|c|}{$\begin{array}{c}\text { (3) } \\
\text { Small \& restrictive }\end{array}$} & \multicolumn{2}{|c|}{$\begin{array}{l}\text { (4) } \\
\text { Small \& restrictive }\end{array}$} \\
\hline & \multicolumn{2}{|c|}{$K=$ currency } & \multicolumn{2}{|c|}{$K=d e b t$} & \multicolumn{2}{|c|}{$K=$ Inflation } & \multicolumn{2}{|c|}{$K=$ curr., debt, inflat. } \\
\hline & Coef. & S.E. & Coef. & S.E. & Coef. & S.E. & Coef. & S.E. \\
\hline Share $e_{t-1}^{\text {crisis }}$ & $0.0157^{* *}$ & $(0.0071)$ & $0.0190^{* * *}$ & $(0.0072)$ & $0.0160 * *$ & $(0.0076)$ & $0.0146^{* *}$ & $(0.0072)$ \\
\hline KMobility & $1.3480^{* * *}$ & $(0.3943)$ & $1.0070^{* * *}$ & $(0.3853)$ & $1.5809^{* * *}$ & $(0.4488)$ & $1.5641^{* * *}$ & $(0.4388)$ \\
\hline Count $_{i, t-1}$ & 0.0201 & $(0.0209)$ & 0.0243 & $(0.0261)$ & 0.0285 & $(0.0212)$ & 0.0124 & $(0.0281)$ \\
\hline Period $_{t}^{1800 ~} 1820$ & $1.3005^{* * *}$ & $(0.3828)$ & $1.3045^{* * *}$ & $(0.4184)$ & $1.4560^{* * *}$ & $(0.3900)$ & $1.5858^{* * *}$ & $(0.4297)$ \\
\hline Period $_{t}^{1821 \sim 1913}$ & $0.8373^{* * *}$ & $(0.2390)$ & $0.5761^{* *}$ & $(0.2370)$ & $0.8735^{* * *}$ & $(0.2718)$ & $0.8749^{* * *}$ & $(0.2567)$ \\
\hline Period $_{t}^{1914 \sim 1945}$ & $1.2924 * * *$ & $(0.3272)$ & $1.1067 * * *$ & $(0.3158)$ & $1.3637^{* * *}$ & $(0.3639)$ & $1.3190^{* * *}$ & $(0.3448)$ \\
\hline Period $_{t}^{1946 ~ ~ 1972}$ & $-2.0467 * * *$ & $(0.7437)$ & $-2.2277 * * *$ & $(0.7309)$ & $-1.9892 * * *$ & $(0.7400)$ & $-2.0089 * * *$ & $(0.7479)$ \\
\hline$G D P_{i, t-1}^{\text {Per Cap }}$ & 0.0346 & $(0.0777)$ & -0.0762 & $(0.0868)$ & 0.1114 & $(0.0818)$ & 0.0060 & $(0.0858)$ \\
\hline Inflation $_{i, t-1}$ & $0.0054^{* *}$ & $(0.0024)$ & $0.0079^{* * *}$ & $(0.0019)$ & $0.0054^{* *}$ & $(0.0023)$ & $0.0053^{* *}$ & $(0.0027)$ \\
\hline Intercept & $-4.5610 * * *$ & $(0.3635)$ & $-4.2607 * * *$ & $(0.3460)$ & $-4.8044 * * *$ & $(0.4158)$ & $-4.6673 * * *$ & $(0.4035)$ \\
\hline Basiss $_{0, i, t}^{\text {banking }}$ & $0.2072^{* *}$ & $(0.0806)$ & $0.1916^{* *}$ & $(0.0794)$ & $0.2954 * * *$ & $(0.0845)$ & $0.2868 * * *$ & $(0.0851)$ \\
\hline Basiss $_{1, i, t}^{\text {banking }}$ & 0.0097 & $(0.0784)$ & -0.0214 & $(0.0774)$ & 0.0442 & $(0.0790)$ & 0.0544 & $(0.0792)$ \\
\hline Basiss $_{2, i, t}^{\text {banking }}$ & $-0.3696^{* * *}$ & $(0.0605)$ & $-0.3856^{* * *}$ & $(0.0654)$ & $-0.3465^{* * *}$ & $(0.0638)$ & $-0.3520^{* * *}$ & $(0.0633)$ \\
\hline Basis $_{3, i, t}^{\text {banking }}$ & 0.0302 & $(0.0791)$ & 0.0141 & $(0.0808)$ & 0.0511 & $(0.0793)$ & 0.0393 & $(0.0825)$ \\
\hline $\operatorname{Basis}_{0, i, t}^{\text {currency }}$ & $-0.1378^{*}$ & $(0.0784)$ & & & & & -0.1285 & $(0.0905)$ \\
\hline Basis currency $_{1, i, t}^{\text {car }}$ & -0.0793 & $(0.0769)$ & & & & & -0.0329 & $(0.0836)$ \\
\hline $\operatorname{Basis}_{2, i, t}^{\text {curency }}$ & 0.1296 & $(0.0924)$ & & & & & 0.1539 & $(0.0981)$ \\
\hline Basiscurrency & -0.0113 & $(0.0864)$ & & & & & -0.0084 & $(0.0822)$ \\
\hline $\operatorname{Basis}_{0, i, t}^{\text {debt }}$ & & & 0.1175 & $(0.0945)$ & & & $0.2164^{* *}$ & $(0.1040)$ \\
\hline $\operatorname{Basis}_{1, i, t}^{\mathrm{debt} t}$ & & & $0.1528^{* *}$ & $(0.0635)$ & & & $0.1760^{* *}$ & $(0.0685)$ \\
\hline $\operatorname{Basis}_{2, i, t}^{\mathrm{debt}}$ & & & -0.0441 & $(0.0777)$ & & & -0.0271 & $(0.0780)$ \\
\hline Basis $_{3, i, t}^{\text {debt }}$ & & & 0.0403 & $(0.0779)$ & & & -0.0146 & $(0.0763)$ \\
\hline Basis $_{0, i, t}^{\text {in faltion }}$ & & & & & $-0.2733^{* * *}$ & $(0.0743)$ & $-0.2635^{* * *}$ & $(0.0736)$ \\
\hline Basisis infaltion & & & & & $-0.2036^{* *}$ & $(0.0915)$ & $-0.2042^{* *}$ & $(0.0845)$ \\
\hline Basis $_{2, i, t}^{\text {infltion }}$ & & & & & -0.0102 & $(0.0667)$ & -0.0589 & $(0.0692)$ \\
\hline Basis $_{3, i, t}^{\text {in faltion }}$ & & & & & 0.0458 & $(0.0735)$ & 0.0537 & $(0.0713)$ \\
\hline Log-likelihood & -786.79 & & -787.51 & & $\begin{array}{l}-783.03 \\
\end{array}$ & & -776.30 & \\
\hline Pseudo $R^{2}$ & 0.0791 & & 0.0783 & & 0.0835 & & 0.0914 & \\
\hline AUROC curve & 0.7131 & & 0.7119 & & 0.7181 & & 0.7340 & \\
\hline $\begin{array}{l}\text { AUROC test } \\
{[p \text {-value }]}\end{array}$ & $\begin{array}{c}3.50 \\
{[0.0615]}\end{array}$ & & $\begin{array}{c}3.52 \\
{[0.0607]}\end{array}$ & & $\begin{array}{c}4.40 \\
{[0.0351]}\end{array}$ & & $\begin{array}{c}12.24 \\
{[0.0070]}\end{array}$ & \\
\hline
\end{tabular}


662 Journal of Economic Integration Vol. 34, No. 4

\section{Appendix 7: Continued}

\begin{tabular}{|c|c|c|c|c|c|c|c|c|}
\hline Sample: & \multicolumn{2}{|c|}{ (1) } & \multicolumn{2}{|c|}{ (2) } & \multicolumn{2}{|c|}{ (3) } & \multicolumn{2}{|c|}{ Small \& restrictive } \\
\hline \multirow[t]{2}{*}{ Non-banking crisis: } & \multicolumn{2}{|c|}{$K=$ currency } & \multicolumn{2}{|c|}{$K=d e b t$} & \multicolumn{2}{|c|}{$K=$ Inflation } & \multicolumn{2}{|c|}{$K=$ curr., debt, inflat. } \\
\hline & Coef. & S.E. & Coef. & S.E. & Coef. & S.E. & Coef. & S.E. \\
\hline $\begin{array}{l}\text { LR test } \\
\qquad[p \text {-value }]\end{array}$ & $\begin{array}{c}6.92 \\
{[0.1403]}\end{array}$ & & $\begin{array}{c}5.47 \\
{[0.2421]}\end{array}$ & & $\begin{array}{c}14.43 \\
{[0.0060]}\end{array}$ & & $\begin{array}{c}27.89 \\
{[0.0057)}\end{array}$ & \\
\hline No. obs. & 4689 & & 4689 & & 4689 & & 4689 & \\
\hline No. countries & 68 & & 68 & & 68 & & 68 & \\
\hline No. crises & 209 & & 209 & & 209 & & 209 & \\
\hline
\end{tabular}

(Note) $* * *, * *$ and $*$ indicate significance respectively at the $1 \%, 5 \%$ and $10 \%$ levels. Cluster robust standard deviations are in brackets. The null hypothesis of the LR test is that the likelihoods are equal in the specifications with and without the basis variables associated with non-banking financial crises. The null hypothesis of the AUROC test is that the AUROC curves are equal in the specifications with and without the basis variables associated with non-banking financial crises. 


\section{Appendix 8: Effect of the banking center status: estimates with the small sample}

\begin{tabular}{|c|c|c|c|c|c|c|c|c|}
\hline Sample: & \multicolumn{2}{|c|}{$\begin{array}{l}(1) \\
\text { Small }\end{array}$} & \multicolumn{2}{|c|}{$\begin{array}{l}(2) \\
\text { Small }\end{array}$} & \multicolumn{2}{|c|}{$\begin{array}{l}\text { (3) } \\
\text { Small \& restrictive } \\
\text { selection rule }\end{array}$} & \multicolumn{2}{|c|}{$\begin{array}{l}\text { (4) } \\
\text { Small \& restrictive } \\
\text { selection rule }\end{array}$} \\
\hline \multirow[t]{2}{*}{$\begin{array}{l}\text { Criteria to define the } \\
\text { variable } \text { Center }_{i, t}\end{array}$} & \multicolumn{2}{|c|}{$\begin{array}{l}\text { Top } 8 \text { banking } \\
\text { centers }\end{array}$} & \multicolumn{2}{|c|}{$\begin{array}{l}\text { Top } 5 \text { banking } \\
\text { centers }\end{array}$} & \multicolumn{2}{|c|}{$\begin{array}{l}\text { Top } 8 \text { banking } \\
\text { centers }\end{array}$} & \multicolumn{2}{|c|}{$\begin{array}{c}\text { Top } 5 \text { banking } \\
\text { centers }\end{array}$} \\
\hline & Coef. & S.E. & Coef. & S.E. & Coef. & S.E. & Coef. & S.E. \\
\hline Share crisis & $0.0211^{* * *}$ & $(0.0063)$ & $0.0207^{* * *}$ & $(0.0064)$ & $0.0174 * *$ & $(0.0073)$ & $0.0174 * *$ & $(0.0074)$ \\
\hline KMobility & $0.9695 * * *$ & $(0.3386)$ & $1.0303 * * *$ & $(0.3342)$ & $1.1469^{* * *}$ & $(0.3690)$ & $1.1654^{* * *}$ & $(0.3677)$ \\
\hline Count $_{i, t-1}$ & 0.0128 & $(0.0260)$ & 0.0150 & $(0.0253)$ & 0.0188 & $(0.0253)$ & 0.0190 & $(0.0238)$ \\
\hline Period $1800 \sim 1820$ & 0.2445 & $(0.3620)$ & 0.2626 & $(0.3560)$ & $1.1505^{* * *}$ & $(0.3795)$ & $1.1301 * * *$ & $(0.3914)$ \\
\hline $\operatorname{Period}_{t}^{1821 ~ ~} 1913$ & 0.0875 & $(0.1996)$ & 0.0819 & $(0.2052)$ & $0.6402^{* *}$ & $(0.2595)$ & $0.6235^{* *}$ & $(0.2639)$ \\
\hline $\operatorname{Period}_{t}^{1914 \sim 1945}$ & $0.6668^{* *}$ & $(0.2721)$ & $0.6856^{* *}$ & $(0.2693)$ & $1.1723^{* * *}$ & $(0.3242)$ & $1.1749^{* * *}$ & $(0.3237)$ \\
\hline $\operatorname{Period}_{t}^{1946 \sim 1972}$ & $-2.5493 * * *$ & $(0.6266)$ & $-2.5271^{* * *}$ & $(0.6267)$ & $-2.1554 * * *$ & $(0.7338)$ & $-2.1420^{* * *}$ & $(0.7335)$ \\
\hline$G D P_{i, t-1}^{\text {Per Cap }}$ & 0.0297 & $(0.0753)$ & 0.0233 & $(0.0761)$ & -0.0176 & $(0.0711)$ & -0.0283 & $(0.0736)$ \\
\hline Inflation $_{i, t-1}$ & $0.0070^{* * *}$ & $(0.0012)$ & $0.0069^{* * *}$ & $(0.0012)$ & $0.0070^{* * *}$ & $(0.0019)$ & $0.0069 * * *$ & $(0.0019)$ \\
\hline Center $_{i, t}$ & $1.0046^{* * *}$ & $(0.2171)$ & $1.6558^{*}$ & $(0.9454)$ & 0.0819 & $(0.2360)$ & 0.1396 & $(0.2731)$ \\
\hline Intercept & $-4.0746^{* * *}$ & $(0.2492)$ & $-4.0985^{* * *}$ & $(0.2484)$ & $-4.3671^{* * *}$ & $(0.3462)$ & $-4.3735^{* * *}$ & $(0.3505)$ \\
\hline Basis $_{0, i, t}^{\text {banking }}$ & 0.0586 & $(0.0583)$ & 0.0641 & $(0.0567)$ & $0.1975^{* *}$ & $(0.0937)$ & $0.1878 * *$ & $(0.0890)$ \\
\hline Basis $_{1, i, t}^{\text {banking }}$ & 0.0136 & $(0.0749)$ & 0.0077 & $(0.0743)$ & -0.0098 & $(0.0873)$ & -0.0259 & $(0.0882)$ \\
\hline Basis $_{2, i, t}^{\text {banking }}$ & $-0.1842 * * *$ & $(0.0656)$ & $-0.1732 * * *$ & $(0.0649)$ & $-0.3453 * * *$ & $(0.0638)$ & $-0.3394 * * *$ & $(0.0609)$ \\
\hline Basis $_{3, i, t}^{\text {banking }}$ & $0.1315^{*}$ & $(0.0790)$ & $0.1324^{*}$ & $(0.0756)$ & 0.0242 & $(0.0779)$ & 0.0335 & $(0.0786)$ \\
\hline Basis $_{0, i, t}^{\text {banking }} \times$ Center $_{i, t}$ & $1.8955 * * *$ & $(0.4913)$ & 3.4649 & (2.5863) & -0.0141 & $(0.1450)$ & 0.0821 & $(0.1791)$ \\
\hline Basis $_{1, i, t}^{\text {banking }} \times$ Center $_{i, t}$ & $-1.1551^{* * *}$ & $(0.3909)$ & -1.9335 & (1.6886) & -0.0609 & $(0.1558)$ & -0.0000 & $(0.1615)$ \\
\hline Basis $_{2, i, t}^{\text {banking }} \times$ Center $_{i, t}$ & -0.2853 & $(0.1823)$ & -0.5100 & $(0.4541)$ & -0.1642 & $(0.1816)$ & -0.2686 & $(0.2095)$ \\
\hline Basiss $_{3, i, t}^{\text {banking }} \times$ Center $_{i, t}$ & -0.0827 & $(0.1919)$ & -0.1541 & $(0.4377)$ & -0.0406 & $(0.2527)$ & -0.0935 & $(0.2471)$ \\
\hline Log-likelihood & -1081.54 & & -1082.48 & & -789.62 & & -788.88 & \\
\hline Pseudo $R^{2}$ & 0.0804 & & 0.0796 & & 0.0758 & & 0.0767 & \\
\hline AUROC curve & 0.7261 & & 0.7230 & & 0.7066 & & 0.7076 & \\
\hline $\begin{array}{l}\text { AUROC test } \\
{[p \text {-value }]}\end{array}$ & $\begin{array}{c}3.34 \\
{[0.0677]}\end{array}$ & & $\begin{array}{c}0.99 \\
{[0.3194]}\end{array}$ & & $\begin{array}{c}0.78 \\
{[0.3776]}\end{array}$ & & $\begin{array}{c}0.86 \\
{[0.3524]}\end{array}$ & \\
\hline $\begin{array}{l}\text { LR test } \\
\qquad[p \text {-value }]\end{array}$ & $\begin{array}{c}5.47 \\
{[0.2425]}\end{array}$ & & $\begin{array}{c}3.60 \\
{[0.4635]}\end{array}$ & & $\begin{array}{c}0.75 \\
{[0.9447]}\end{array}$ & & $\begin{array}{c}1.64 \\
{[0.8018]}\end{array}$ & \\
\hline No. obs. & 7424 & & 7424 & & 4689 & & 4689 & \\
\hline No. countries & 70 & & 70 & & 68 & & 68 & \\
\hline No. crises & 275 & & 275 & & 209 & & 209 & \\
\hline
\end{tabular}

(Note) $* * *, * *$ and $*$ indicate significance respectively at the $1 \%, 5 \%$ and $10 \%$ levels. Cluster robust standard deviations are in brackets. The null hypothesis of the LR test is that the likelihoods are equal in the specifications with and without the 4 interaction variables. The null hypothesis of the AUROC test is that the AUROC curves are equal in the specifications with and without the 4 interaction variables. 


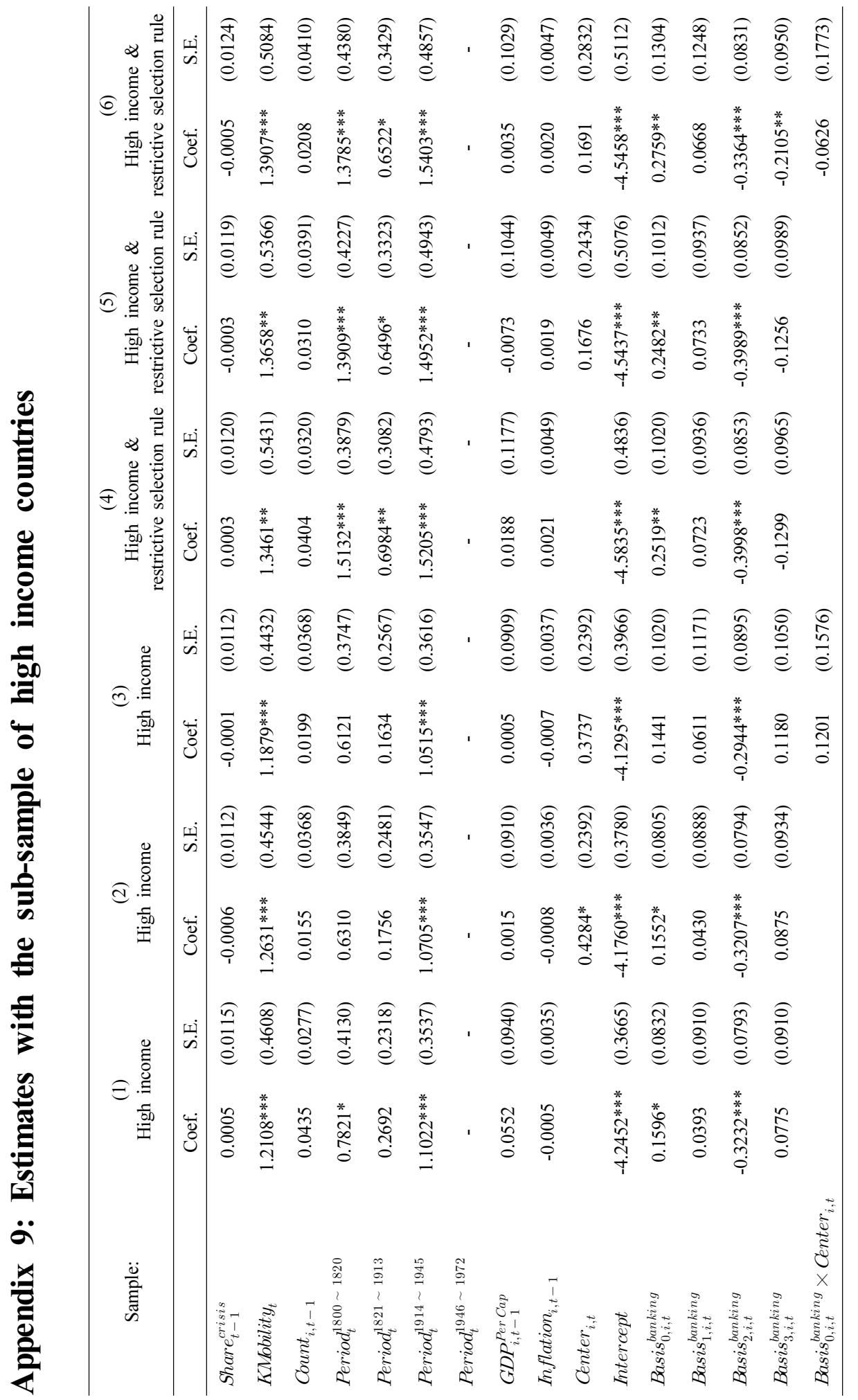




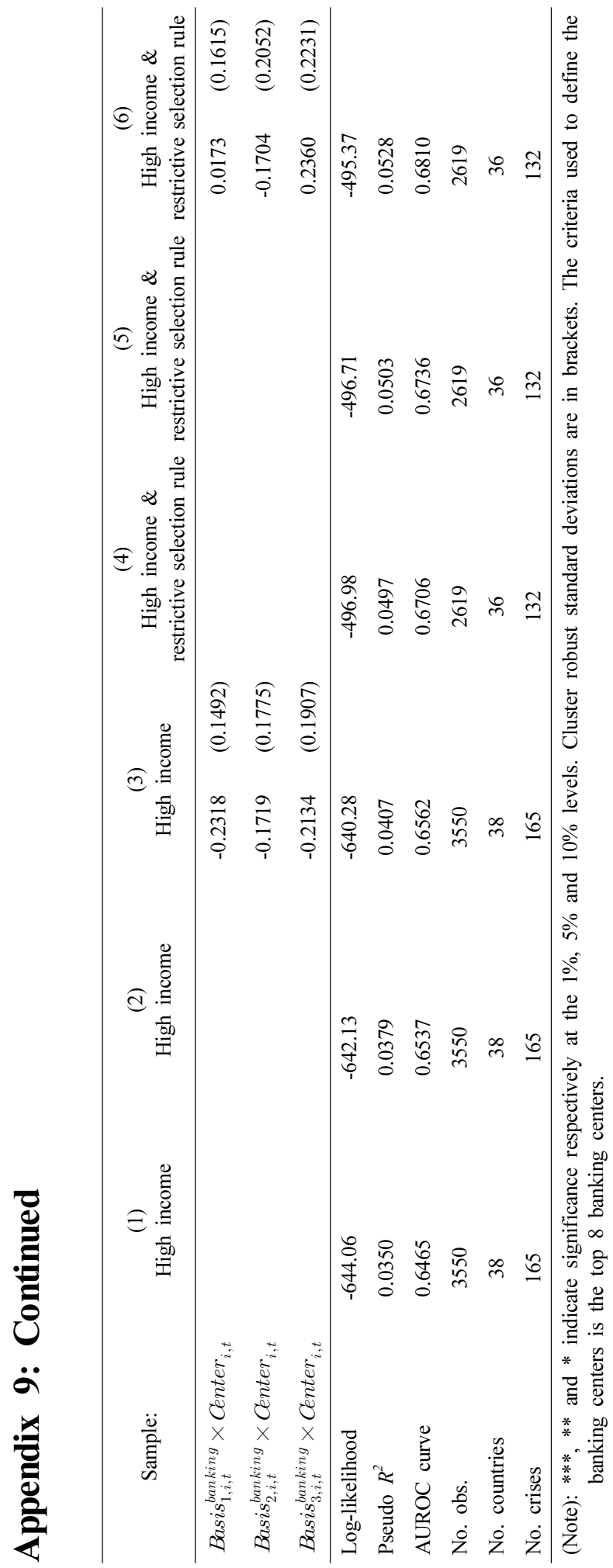


666 Journal of Economic Integration Vol. 34, No. 4

\section{Appendix 10: Time dependence in banking crises: subsample of high income countries}

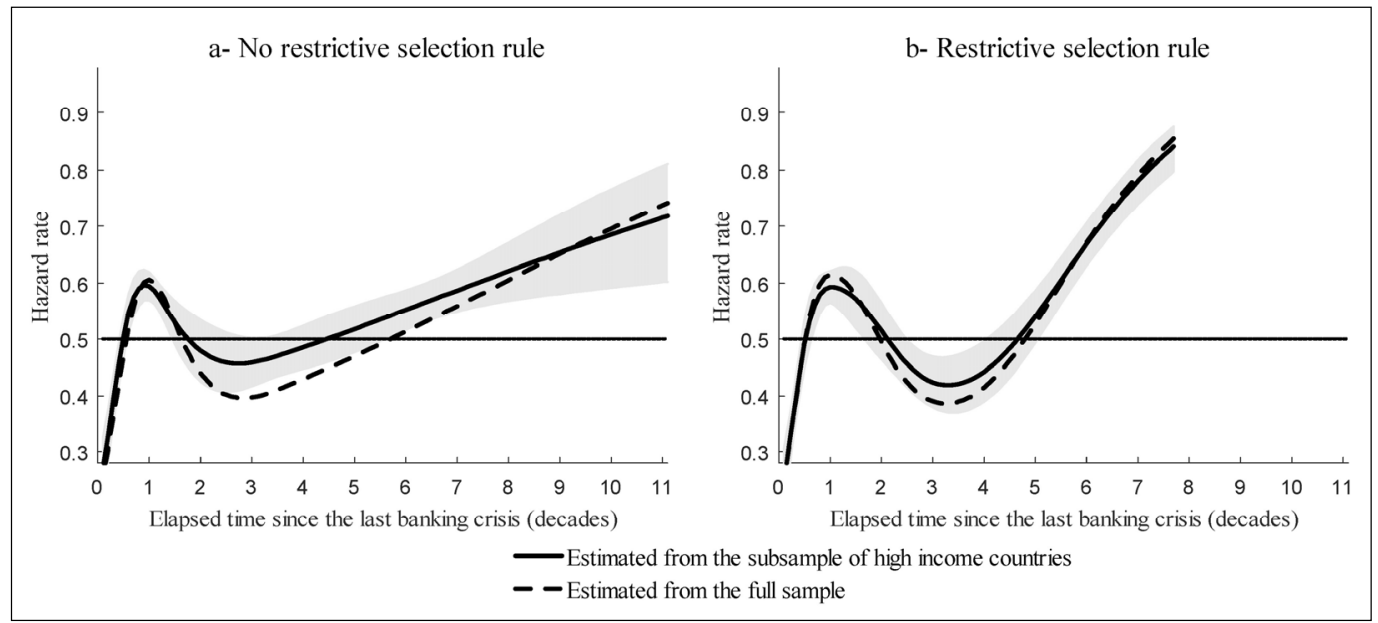

(Note) the grey area corresponds to the one-standard error band (for the estimate from the subsample) 